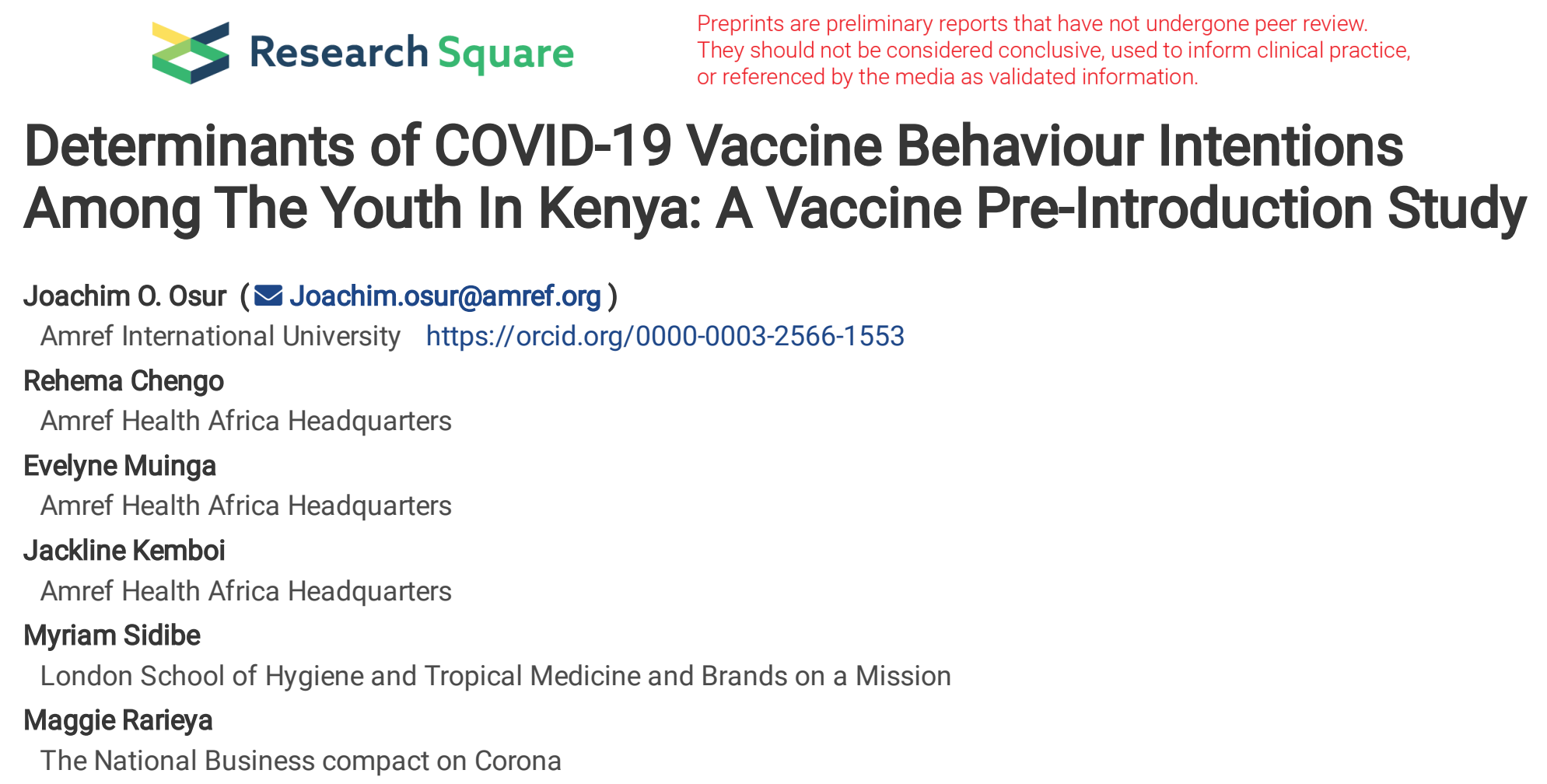

\section{Determinants of COVID-19 Vaccine Behaviour Intentions Among The Youth In Kenya: A Vaccine Pre-Introduction Study}

Joachim 0. Osur ( $\square$ Joachim.osur@amref.org )

Amref International University https://orcid.org/0000-0003-2566-1553

\section{Rehema Chengo}

Amref Health Africa Headquarters

\section{Evelyne Muinga}

Amref Health Africa Headquarters

Jackline Kemboi

Amref Health Africa Headquarters

Myriam Sidibe

London School of Hygiene and Tropical Medicine and Brands on a Mission

Maggie Rarieya

The National Business compact on Corona

\title{
Research
}

Keywords: vaccine hesitancy, safety, effectivenes

Posted Date: September 29th, 2021

DOI: https://doi.org/10.21203/rs.3.rs-910474/v1

License: (c) (1) This work is licensed under a Creative Commons Attribution 4.0 International License. Read Full License 


\section{Abstract}

Background: COVID-19 has become a public health concern globally with increased numbers of cases of the disease and deaths reported daily. The key strategy for the prevention of COVID-19 disease is to enhance mass COVID-19 vaccination. However, mass vaccination faces challenges of hesitation to acceptance of the vaccine in the community. The youths may not be among the vulnerable population to adverse effects of COVID-19 but are highly susceptible to contracting the virus. The aim of the study was to assess COVID-19 vaccine youth behavior intentions and their determinants in Kenya.

Methods: The study used a mixed method study design, employing a cross-sectional survey and focused group discussions across 47 counties in Urban, Peri-Urban and Rural settings. The interviewees were youths aged 18-35, registered in online platforms that included Shujaaz, Brck Moja, Aiffluence, Y Act and Heroes for Change. Quantitative data was collected using Google docs while the Focus Group Discussions (FGDs) were done virtually. A total of 637 interviews and 4 FGDs were done. Quantitative data was analysed using STATA version 16. Qualitative data was analyzed using MAXQDA software.

Results: The findings of the study indicated that only $42 \%$ of the youths were ready to be vaccinated, $52 \%$ were not ready to be vaccinated adopting wait and see approach to what happens to those who had received the vaccine, and $6 \%$ were totally not willing to be vaccinated. The determinants of behavior intention among the youths were; the perceived effects the vaccine on health, lack of adequate information about the COVID-19 vaccine, too much conflicting information about COVID-19 vaccine from the social media, religion, education level, perceived risk of contracting the COVID-19 disease, efficacy of the COVID-19 vaccine, gender, trust in the ministry of health, and the belief that the COVID-19 vaccine was harmful to the populations.

Conclusion: The Vaccine hesitancy among the youths was found to be $58 \%$. The Hesitancy is higher among females, protestants, those with post-secondary education. Lack of information and concerns around vaccine safety and effectiveness were main cause of COVID-19 vaccine hesitancy among the youths. Social media was the major source of information contributing to hesitancy. Other contributors included; low trust in the $\mathrm{MoH}$, belief that mass vaccination is not helpful

\section{Background}

Coronavirus disease 2019 (COVID-19) is an infectious viral disease spread through respiratory droplets. COVID-19 spreads through aerosols when people are in close contacts such as in crowded places and places with poor ventilation (WHO, 2020). The rapid spread of COVID-19 disease has caused significant strain to health systems, led to deaths and ill health, and raved economies globally (Lazarus et al., 2020; Tam, Qiao \& Li, 2020; Richmond et al., 2020; Larson et al., 2021)

The confirmed cases of COVID-19 have risen globally with over 96,658,420 cases and 2, 092,062 deaths reported as of $23^{\text {rd }}$ January 2021. In Africa approximately 2, 395,260 cases and 55,644 deaths were confirmed, while in Kenya 99,444 cases and 1,736 deaths have been confirmed (WHO, 2021).

Several measures have been put in place to contain the disease including social distancing, wearing of masks and washing of hands, or use of disinfectants (WHO, 2020). Additionally, it is anticipated that vaccination of the population will help to prevent transmission of the disease. The world is racing to get an effective and safe vaccine with the aim of vaccinating a critical mass of the world population to achieve herd immunity (Kwok et al., 2020)

The greatest concern right now is that populations may not fully accept the COVID-19 vaccine when it becomes available. Increasing vaccine hesitancy and resistance have been noted globally (Kennedy, 2020; Richmond et al., 2020; WHO, 2019; WHO, 2020). Vaccine resistance and hesitancy can be caused by numerous factors including misinformation, lack of knowledge on vaccines, myths, social norms, traditional and religious beliefs, misconceptions, incitement from peers and politicians (Tam, Qiao \& Li, 2020.; Fadda et al., 2020).

Page 2/31 
Additionally, safety and efficacy concerns of the vaccine can affect uptake and increase hesitancy (Gadoth et al., 2020). Evidence shows that vaccine efficacy and safety concerns have a strong relationship with an individual's willingness to accept to receive the COVID-19 vaccine (Guo et al., 2017). Also, the belief that the vaccine will have adverse side effects results in lowered confidence in the COVID-19 vaccine and it will lower an individual's willingness to be vaccinated; hence low levels of uptake of a vaccine (Kreps et al., 2020; WHO, 2020).

An individual's motivation for a vaccination with the COVID-19 vaccine is influenced by their confidence in the vaccine, feelings, and how they perceive themselves to be at risk of contracting COVID-19 disease. If people think they are at low risk of contracting the disease, they are likely to be less motivated to vaccinate with the COVID-19 vaccine. If they feel the vaccine is not beneficial, they are less likely to be motivated to receive the vaccine (WHO, 2020). Lack of knowledge of the risks of not being vaccinated and the benefits of the COVID-19 vaccine is also a contributing factor to the lack of intentions to receive the vaccine once it is made available to the populace (Guzman-Holst et al., 2020).

Research shows that individuals who don't perceive to be at risk of infections are less likely to be vaccinated. A review of the study of H1N1 revealed that one of the major determinants of intentions to accept a vaccine is not being bothered about the influenza vaccine. This is likely to lower vaccine demand among the youths, hence lower uptake of the vaccine. Also, when a group of people believes that a disease is mild, the intentions to receive the vaccines are lowered (Mills et al., 2020).

Moreover, conspiracy theories and vaccine opposition are increasing across the world as moves to roll out the COVID-19 vaccine are being put in place (The COCONEL Group, 2020). In Nigeria and Pakistan, research reveals that waves of misinformation about polio vaccine which has been circulating in the social media, as well as religious extremism have led to a decline in uptake of the polio vaccine, hence increased cases of polio in the respective countries (Malik et al., 2020).

The severity of COVID-19 disease occurs in people with advanced age as well as those with diabetes, hypertension, heart disease, and cancer compared to young people (WHO, 2020; Sticchi et al., 2020). However, the youths may be more susceptible to contracting COVID-19 disease than older people, because of their low perceived risks, which may result in transmitting the disease to their loved ones. Also, health workers who are also exposed to infection by the nature of their work, also suffer a high burden of disease. In a phased-off COVID-19 vaccine approach, therefore, health workers, the elderly, and those with pre-existing health conditions will be prioritized for COVID-19 vaccination. It is however important to note that acceptance of the vaccine by these groups is not necessarily given. Vaccine hesitancy is known to be a household and community behavior rather than just individual health-seeking behavior. The WHO Technical Advisory Group on Behavioral Insights and Sciences for Health has prioritized social influence as an important factor in determining COVID-19 vaccine uptake (WHO 2020). As such, health workers, as well as the aged and people living with pre-existing health conditions, are likely to be influenced by and also influence the youth in their behavior intentions towards the COVID-19 vaccine.

The role of social media is identified as an important factor in social influence. The youth have access to social media and are likely to interact much more with negative messages and conspiracy theories on COVID-19 vaccination which may lead to vaccine hesitancy (Feemster, 2020; Wilson \& Wiysonge, 2020; Puri et al, 2020). They are likely to not only develop vaccine hesitancy through the influence of social media but also act as agents of vaccine hesitancy in their families and communities (Burgess et al., 2020). Other studies have similarly found that adults are influenced by their social contacts in accepting vaccination and the social circle may involve the youth that they associate with (American Psychological Association 2020). However, there are no studies done to establish the behaviour intentions of youth on the COVID-19 vaccine and the determinants of the intentions (Wilson \& Wiysonge, 2020).Studying COVID-19 behavior intentions and their determinants among the youth is an important entry point to understanding possible vaccine hesitancy issues in families and communities and help in designing behaviour change communication for increasing vaccine uptake among all members of the community. 


\section{Methods}

\section{Aim of the study}

The main aim of the study was to assess COVID-19 vaccine youth behavior intentions and their determinants in Kenya. Specifically, the study sought to determine COVID-19 vaccine health seeking behavior intentions and establish determinants of COVID vaccine health seeking behavior intentions on COVID-19 vaccine among the youth in Kenya

\section{Study design}

This study utilized mixed-method study using a cross-sectional survey and focused group discussions approaches. Determinants of behavior intentions on the COVID-19 vaccine among the youths were measured quantitatively by crosssectional survey while focused group discussions was used to establish the reasons behind the variables measured.

\section{Study setting and target population}

The study was conducted in 47 counties of Kenya covered by the online platforms. The target population were youths aged 18- 35 years as per the 2010 Kenyan constitution. The online platforms had a list of actively registered users, which made it easy for them to be sampled. The NBCC a partner in the study put together social businesses that targeted the youth and had identified the platforms that they had registered in Heroes4Change, Aifluence, MojaWifi, Brick Moja, Y act, and Shujaaz Inc. Youths who had registered and were active in the online platforms were eligible to take part in the study. The study excluded inactive registered users as well as unregistered youths that were not on the online platforms. In addition, youths who refused to give consent to participate in the study were excluded from the study.

\section{Sampling techniques and sample size determination}

\subsubsection{Sampling technique}

The number of active youths registered on the online platforms formed the sampling frame for the study. Convenient sampling was used to select the online platforms because they contained the target population and the population who could access online surveys. The youths were selected from each online platform randomly, proportional to the number of registered youths taking into account varied platform characteristics.

\subsubsection{Sample size determination}

There were 53289 active registered online platform users in the areas of study, that is, Shujaaz Inc. 40000; Brck Moja 6,000; $\mathrm{Y}$ act 3,000; Heroes4Change 419 and Alfluence 3870. Krejcie and Morgan sampling formula (1970) was used to determine the sample size of the youths to be surveyed in each platform because the number of registered youths on the online platform is known.

$$
s=\chi^{2} \mathrm{NP}(1-\mathrm{P}) \div \mathrm{d}^{2}(\mathrm{~N}-1)+\chi^{2} \mathrm{P}(1-\mathrm{P})
$$

Where,

$\mathrm{s}=$ required sample size 
$\mathrm{X}^{2}=$ the table value of chi-square for 1 degree of freedom at the desired confidence level $p=0.05(3.841)$

$N=$ the population size (53289)

$d=$ with the degree of accuracy expressed as proportion (0.05)

$10 \%$ of the sample size was added to the original sample to account for non-response or attrition rates.

A total of 665 youths were drawn from the five platforms. The sample was distributed proportionately according to the number of registered members per platform. Simple random sampling was used to select youths to be surveyed from each platform.

Four FGDs were conducted, whereby the participants of the FGDs involved leaders and members of the various online platforms sampled from the 47 counties.

\section{Development of research instruments}

The focus group discussion guide and the cross-sectional survey structured questionnaires were adapted from the Health Belief Model (HBM), Theory of Planned Behavior (TPB), and WHO SAGE matrix (WHO, 2011). The questions focused on examining the determinants of behaviors on the COVID-19 vaccine and behavior intentions on accepting or hesitating to take up the vaccine when available to the youths.

\section{Data Collection Techniques}

The quantitative data collection was administered using google forms. The questionnaires were designed on Google forms, and then the database secured using a strong password. An automatic web URL link was generated and the link was shared to the research assistants via the email. The first section of the form contained the consent form, of which the participants were only allowed to participate once they consented.

Focused group discussions were conducted through zoom meeting, where the participants were provided with login details by the facilitator.

\section{Data Management and Analysis}

The quantitative data collected from the study was transferred into STATA version 16, cleaned, and coded for analysis. The results of the quantitative variables are summarized into descriptive statistics (percentage and frequency tables). The univariate analysis was used to analyze continuous variables while chi-square test was used to analyze categorical variables to establish the determinants of behavior intention amongst the youths on the COVID-19 vaccine. Structural equation modeling was employed to establish the significant association of HBM and TPB that might have a considerable effect on youth's intention to accept the COVID-19 vaccine. FGD recordings were transcribed, entered into MAXQDA software, then coded into themes, and analyzed.

\section{Results}

\subsection{Demographics Data}

The sample included 665 youths $(60.30 \%$ male) and (30.70\% females) among which $45.35 \%$ were from urban counties, $26.36 \%$ and $28.29 \%$ are from peri-urban and rural counties respectively. Majority $(55.34 \%)$ of the youth interviewed were aged 18 to 23 years, $41.03 \%$ are from urban counties, $31.25 \%$ are from rural counties and minority $27.72 \%$ are from peri urban counties. Among the youth surveyed, majority $48.88 \%$ of them were protestants and lived in urban counties. The 
education level of the majority of the youths interviewed were college/university where $64.21 \%$ of them came from urban counties. See Table 1

\subsection{Behavior Intentions}

Overally, $52 \%$ of the youths surveyed reported that they will wait and see how people who were vaccinated would react to COVID-19 vaccine before they can get it, $42 \%$ reported that they will be among the first people to take it (Fig. 1). In contrast, $6 \%$ of the youths stated they will not take the vaccine.

Disaggregating by gender, the study revealed that majority $60.85 \%$ of the females will wait and see how other people react to the vaccine before they can get it while majority $47.38 \%$ of male participants will be among the first people to get the vaccine. Statistically there was a significant difference between gender and uptake of COVID 19 vaccine (Chi square $P$ Value $0.004<0.05$ at $95 \%$ C.I). Further test shows a moderate association between gender and uptake of COVID 19 vaccine (Cramer's $\mathrm{V}=0.1080)$. The study also revealed a significant relationship between religion and vaccine uptake (Chi square $\mathrm{P}$ Value $0.001<0.05$ at $95 \%$ C.I). See Table 2.

The results revealed that there was a widening gap in access to the COVID vaccine among females and males, sometimes men tending to access the vaccine more than the women. The reasons behind gender inequality were stated as follows;

\section{Toxic masculinity}

The youths in the focused group discussions reported that the society esteem men more compared to women, and this makes women feel that men should always be at the forefront in everything. Some women are not able to make independent choices and decisions and therefore they have to consult their partners, that is they can't do anything without being allowed by their partners.

Society generally holds men in higher regard than women, the society has made women feel men should be at the forefront. some women can't make independent choices and therefore have to consult partner. (FGD)

patriarchal society so women can't do something without being allowed by husbands or fathers despite being of legal decision making age

\section{Health reasons}

The COVID-19 vaccine is contraindicated for pregnant women and breastfeeding mothers, and therefore they cannot be vaccinated. The women are more cautious when it comes to their health and they think they are not exposed to the virus, hence they don't need to be vaccinated.

if a woman is breast feeding or pregnant, vaccine is contraindicated; shouldn't take FGD

I would say are from women in terms of maybe more women have more reservations in taking the vaccine perhaps most of my colleagues would is say does it have an effect on fertility on my immune system, I think women take more caution when it comes to their health and in their lives so the easier way is that so long as they do not feel like they are exposed to the virus they are more likely to stay home than get the virus. FGD

\section{Men have weak immunity and suffer from the disease more compared to women:}

Men were perceived to have weak immunity compared to women, thus if they contract the disease, if not vaccinated they would die easily. When the women receive this kind of information from the media, they tend to be reluctant to take up the vaccine as they think they are safer compared to men. Also, men are more affected by the disease more compared to the women. 
"many people have said that more men when they get this COVID they can easily die from it as compared to women, I think it's because of immune system, and that's why most women they just like ignore, I don't think it's ignoring because most women they don't choose to just go for the vaccine because of what is said by the media that women are not highly affected to the point of death as compared to men." $\sim \mathrm{FGD}$

"The male gender the suffering the virus a big deal more than the female and it's also surprising that the females are also getting the vaccine So much than the male gender and that's not working out because it's not logical, whereby the men are the gender that is suffering, mostly from the virus but they are getting the least supplies." $\sim F G D$

\section{Access to COVID-19 vaccine information}

The men were reported to have high access to COVID-19 vaccine information compared to women because most men go outside their houses to clubs where they meet with their peers where they share more information on the COVID-19 vaccine. Women most of the times remain at home doing house chores and have less access to information about the COVID-19 vaccine, thus will not go for the vaccine as they lack the right information.

Women tend to be busier than men - work and attend to matters at home so getting time to go for vaccine is harder.

More women work at home and so access to information is less giving men a higher chance to also get vaccinated as the access info easily and can pass by the hospital and get vaccinated. women go home to do household chores in the evening while men go to bars, hotels, etc to chill hence have access to information. FGD

\section{Occupation}

The type of occupation exposes people to risks of contracting COVID-19 disease, and people at risk are encouraged to take up the vaccine. Men most of the time are the bread winners for their families and will always go out to work so that they can provide for their families. Thus will access information about the vaccine and get the vaccine compared to women who don't go out to search for the bread. Due to the exposure to the risks of contracting the disease, men will be more likely to be vaccinated compared to women.

I know of households where the men are the main breadwinners, so they go to work every single day. So that's why more of them are getting the vaccine cause they're out there, they're traveling a lot, they have to do that every single day, so they go get the vaccine first before some women do not all but some. FGD

In Kenya you find that we have more men who go out to hustle or work and we have a section of women who are left behind, the people who go out have a higher risk of being infected and the wives will push for the men to be vaccinated because they feel like it is through the person who is going out that they will get the virus. FGD

\section{Nature of men Vs women}

Women feel that their bodies are more complicated to men's and need to be protected from any complications associated with the vaccine, and since men's body is not complicated, they can risk to get the vaccine.

The body set up the female body is more complicated than the men and they say let them protect themselves first and not go for the vaccine. And the men are not complicated and they would take the risk. FGD

\section{Perceived behavior control}

Men were perceived to be more careless than women in adherence to COVID-19 guidelines, and hence will be more exposed to risks of contracting the disease compared to women. Therefore, for proper protection they require to be vaccinated. 
Women are more skeptical and will need more information to help them make the right decisions compared to men who are risk takers. Men will make decision to take up the vaccine without consulting their wives but women have to consult.

"Men tend to be more careless when it comes to the covid guidelines. Men are risk takers but women are more skeptical so need more information to make decisions and men make decisions without having to consult with their wives, but women keep consulting." $\sim F G D$

you find that it's the male who are actually exposed as compared to women, and I would look at it in the, I think it's the not to judge on it or rather a different perspective, but I would look at it, it's the simple behaviors that women are exposed to, and men are exposed to, like you would look at it in the sense that a woman would wash their hands as many times as compared to how meals wash their hands, so that that would bring it down to like the chances of being exposed. FGD

\section{Accessibility of the COVID-19 vaccine / Lack of transport}

Women's duty of house chores and taking care of the children make them unable to access the COVID-19 vaccine. Lack of transport/ enough money to take their children to daycare and to facilitate their transport to vaccination centers hinder them from accessing the COVID-19 vaccine.

"The vaccine is not really that easily accessible, so for a woman who's taking care of her kids at home." FGD

"I think that Maybe there are challenges that the women are facing that is preventing them from being vaccinated, maybe I can say transport, may be taking care of children, so to make this equal, I think they should be provided with the transport or like maybe building daycares for taking their children to be looked after there as they go for the vaccine. so that can make it for them to be equal, yeah, that is my view." FGD

\section{Fear of becoming infertile}

Women hesitate to take the vaccine because they fear their hormones will be suppressed and may make them get few children. Men are less concerns about the effects of the vaccine and will prefer to take it despite the effects.

"I think most females have that fear, like a woman would have that fear and it will be like the their hormones will be suppressed when they get access to the vaccine as compared to a male who will be like I would rather just take it, the male won't look at it in a deeper perspective considering the myths that are there that women there is a chance that you will get less children, there is a chance that this might happen it will affect your hormones and everything, so I think that would bring it down to why most males are getting the vaccine as compared to females, yeah that's my opinion, thank you. " FGD

\section{Myths and misinformation}

Myths which target women, that the vaccine could be more harmful after taking it compared to when not taken, hence the hesitancy among women. They also belief that COVID-19 disease is not real and God can protect them from any disease.

"Existing myths target ladies more hence their hesitance towards uptake of vaccine. They belief that it could be more harmful when taken than without taking it." $\sim F G D$

"Belief that corona isn't real; and that God would protect them from any disease." $F G D$

Rumours that the vaccine will interfere with the menstrual cycle of the women. That the vaccine is likely to cause missed periods or even affect their health. This results to low uptake of the vaccine among the women.

"According to the here say of women who have taken the vaccine before, there is something going around that they missed their periods, something like that, so when the rest of the gender gets to here that they tend to hold back on taking the vaccine." $\sim F G D$ 
"Generally, people have started being skeptical about the vaccines due to their effects on the woman's body as evidenced by the HPV vaccine which also experienced very low turnout. So, all the misconceptions and myths plus side effects could cause low uptake" FGD

Table 1

Socio-demographic data

\begin{tabular}{|c|c|c|c|c|}
\hline \multirow[t]{2}{*}{ Variable } & \multirow{2}{*}{$\begin{array}{l}\text { General Sample } \\
\mathrm{n}(\%)\end{array}$} & \multicolumn{3}{|l|}{ Urbanization } \\
\hline & & $\begin{array}{l}\text { Urban Counties } \\
n(\%)\end{array}$ & Peri-Urban Counties n(\%) & $\begin{array}{l}\text { Rural Counties } \\
n(\%)\end{array}$ \\
\hline Gender & $258(38.80)$ & $117(45.35)$ & $68(26.36)$ & $73(28.29)$ \\
\hline Female & $401(60.30)$ & $179(44.64)$ & $110(27.43)$ & $112(27.93)$ \\
\hline Male & $6(0.90)$ & $3(50.0)$ & 2(33.33) & $1(16.67)$ \\
\hline \multicolumn{5}{|l|}{ Prefer not to say } \\
\hline Age & $368(55.34)$ & $151(41.03)$ & 102(27.72) & $115(31.25)$ \\
\hline 18 to 23 years & $249(37.44)$ & $125(50.5)$ & $61(24.50)$ & $63(25.30)$ \\
\hline 24 to 29 years & $48(7.22)$ & $23(7.69)$ & $17(35.42)$ & $8(16.67)$ \\
\hline \multicolumn{5}{|l|}{ 30-35 years } \\
\hline Religion & $289(43.46)$ & 112(38.75) & $83(28.72)$ & $94(32.54)$ \\
\hline Catholic & $15(2.26)$ & $10(66.67)$ & $3(20.00)$ & $2(13.33)$ \\
\hline Islam & $3(0.45)$ & $2(66.67)$ & $1(33.33)$ & $0(0.00)$ \\
\hline No Religion & $358(53.83)$ & $175(48.88)$ & $93(25.98)$ & $90(25.14)$ \\
\hline \multicolumn{5}{|l|}{ Protestant } \\
\hline Education Level & $417(62.71)$ & 192(45.93) & $104(24.88)$ & $122(29.19)$ \\
\hline College/university & $19(2.86)$ & $8(42.11)$ & $8(42.11)$ & $3(15.79)$ \\
\hline Primary & $229(34.44)$ & $99(43.42)$ & $68(29.83)$ & $62(26.75)$ \\
\hline Secondary & & & & \\
\hline
\end{tabular}


Table 2

Socio demographic factors by intention to get CoVID-19 vaccine

\begin{tabular}{|c|c|c|c|c|}
\hline Variable & $\begin{array}{l}\text { I want to be among the } \\
\text { first people to get it } \\
n(\%)\end{array}$ & $\begin{array}{l}\text { I will not get } \\
\text { the vaccine n } \\
\text { (\%) }\end{array}$ & $\begin{array}{l}\text { I will wait to see how other people } \\
\text { react to it before I can get it } n(\%)\end{array}$ & $\begin{array}{l}\text { P- } \\
\text { Value(Cramer's } \\
\text { V) }\end{array}$ \\
\hline Age & $150(40.76)$ & $15(4.08)$ & $203(55.16)$ & 0.064 \\
\hline 18 to 23 years & $110(44.18)$ & $22(8.84)$ & 117(46.99) & \\
\hline 24 to 29 years & 18(37.50) & $2(4.17)$ & 28(58.33) & \\
\hline \multicolumn{5}{|l|}{$30-35$ years } \\
\hline Gender & 87(33.72) & $14(5.43)$ & 157(60.85) & \multirow{4}{*}{$\begin{array}{l}0.004^{* * *} \\
(0.1080)\end{array}$} \\
\hline Female & $190(47.38)$ & $24(5.99)$ & 187(46.63) & \\
\hline Male & $1(16.67)$ & $1(16.67)$ & $4(66.67)$ & \\
\hline \multicolumn{4}{|l|}{ Prefer not to say } & \\
\hline Religion & $148(51.21)$ & $10(3.48)$ & $131(45.33)$ & \multirow{5}{*}{$\begin{array}{l}0.001 * * * \\
(0.1301)\end{array}$} \\
\hline Catholic & $4(26.67)$ & $1(6.67)$ & $10(66.67)$ & \\
\hline Islam & $2(66.67)$ & $0(.00)$ & 1(33.33) & \\
\hline No Religion & $126(34.64)$ & $28(7.82)$ & $206(57.54)$ & \\
\hline \multicolumn{4}{|l|}{ Protestant } & \\
\hline Education Level & $149(35.65)$ & $29(6.94)$ & $239(57.42)$ & \multirow{4}{*}{$\begin{array}{l}0.001 * \star \star \star \\
(0.1172)\end{array}$} \\
\hline College/university & $8(42.11)$ & $1(5.26)$ & $10(52.63)$ & \\
\hline Primary & $121(53.07)$ & $9(3.95)$ & $99(42.98)$ & \\
\hline \multicolumn{4}{|l|}{ Secondary } & \\
\hline County Category & $84(46.67)$ & $8(4.44)$ & $88(48.89)$ & \multirow[t]{4}{*}{0.139} \\
\hline Peri Urban & $85(45.70)$ & $10(5.38)$ & $91(48.92)$ & \\
\hline Rural Counties & $109(36.45)$ & $21(7.02)$ & $169(56.52)$ & \\
\hline Urban Counties & & & & \\
\hline
\end{tabular}

Stratified by education level, the study revealed a significant relationship between educational level and COVID 19 vaccine uptake (Chi square P Value $0.001<0.05$ at $95 \%$ C.I). Further analysis showed a moderate association between education level and COVID 19 vaccine uptake (Cramer's v $=0.1172)$.

The multinomial logistic regression model for predicting the uptake of COVID-19 vaccine is shown in Table 3 . The results suggest that male predictor are 0.5538 less likely to wait to see how other people react to the vaccine before they can get it and are more likely to be among the first people to get the vaccine compared to females $(b=-.5538$, s.e. $=.1730, p=.0 .001)$ (see Fig. 2).

The youths with primary level of education are 0.6405 more likely to get the vaccine and more likely to be among the first people to get the vaccine compared to respondents with tertiary/University level of education $(b=-0.473$, s.e. $=1.1047, p$ $=.024)$. In addition, the respondents with secondary level of education are less likely to wait and see how people react to the vaccine before they can get it but are more likely to be among the first people to get the vaccine compared to compared to respondents with tertiary/University level of education $(b=-0.6405$, s.e. $=0.31754, p=.0 .00)$ see Fig. 3 . In summary, 
respondents with lower level of education are willing to get vaccinated compared to counterparts with higher level of education.

On the other hand, protestants are 1.1485 less likely to get vaccinated and more likely to wait to see how other people react to it before they can get it $(b=1.1485$, s.e. $=.3905, p=.0 .003)$. In addition, they are also 0.5853 less likely to be among the first people to get the vaccine compared to Catholic $(b=0.5853$, s.e $=0.1689, p=0.001)$ see Fig. 4 .

The surveyed youths were asked if their friends and relatives are ready to receive the COVID 19 vaccine and the majority $59.9 \%$ thinks that their relatives are friends are ready to receive the COVID 19 vaccine as shown in Fig. 5.

Table 3

Associated factors of uptake of COVID-19 using a multivariable multinomial regression

\begin{tabular}{|c|c|c|c|c|c|c|}
\hline \multirow[t]{2}{*}{ Variable } & \multicolumn{3}{|c|}{ I will not get the vaccine $n(\%)$} & \multicolumn{3}{|c|}{$\begin{array}{l}\text { I will wait to see how other people react to it } \\
\text { before I can get it } n(\%)\end{array}$} \\
\hline & Coefficient & $\begin{array}{l}\text { Standard } \\
\text { error }\end{array}$ & P-value & Coefficient & Standard error & P-value \\
\hline Gender & -0.1600 & 0.3655 & 0.662 & -0.5538 & 0.1730 & $0.001^{* * *}$ \\
\hline (reference Predictor-Female & 1.5445 & 1.4650 & 0.292 & 0.5979 & 1.1355 & 0.599 \\
\hline \multicolumn{7}{|l|}{ Male } \\
\hline \multicolumn{7}{|l|}{ Prefer not to say } \\
\hline Religion & 1.3392 & 1.1772 & 0.253 & 1.0352 & 0.6138 & 0.092 \\
\hline (reference predictor- Catholic) & -10.6582 & 489.341 & 0.983 & -0.6089 & 1.2348 & 0.622 \\
\hline Islam & 1.1485 & 30.3905 & $0.003^{\star \star \star}$ & 0.5853 & 0.1689 & $0.001^{\star * \star}$ \\
\hline \multicolumn{7}{|l|}{ No Religion } \\
\hline \multicolumn{7}{|l|}{ Protestant } \\
\hline Education Level & -0.9131 & 0.4046 & 0.670 & -0.6405 & 0.1754 & $0.000 * \star \star$ \\
\hline $\begin{array}{l}\text { (Reference Predictor- } \\
\text { College/university) }\end{array}$ & -0.473 & 1.1047 & $0.024 * \star \star$ & -0.1769 & 0.4990 & 0.723 \\
\hline \multicolumn{7}{|l|}{ Secondary } \\
\hline Primary & & & & & & \\
\hline
\end{tabular}

$65 \%$ of the youths correlated the rejection of COVID 19 vaccine to inadequate information, effectiveness of the drug and safety was $42 \%$ and $45 \%$ respectively. Only $7 \%$ of the youths reported that their reason for rejecting the COVID 19 vaccine was due to conflict with culture or religion see Fig. 6.

From Fig. 6 above, Majority reported that the main reason for rejecting the COVID 19 vaccine was due to inadequate information. The study further revealed that majority of the youths $29.61 \%$ reported to strongly agree with the reason for rejecting COVID_19 vaccines. See Fig. 7

The most common source of information about COVID-19 vaccines was reliance on social media $40.30 \%$. This was followed by TV programs and radio, $31.43 \%$ and $23.91 \%$ respectively, word of mouth was $2.56 \%$, while IEC material from $\mathrm{MOH}$ was the main source of information for $1.35 \%$ of the youth see Fig. 8

Chi square test was used to determine the relationship between socio-demographic factors and the main source of COVID 19 information, gender, educational level and county of residence was found to be associated with the main source of 
information with (P-value $<0.05$ at $95 \% \mathrm{Cl}$ ). Social media platforms were the main source of information about COVID-19 among the female youths, respondents residing in urban counties and respondents with college/university educational levels. The male respondents preferred radio as the source of COVID 19 information compared to female. On the hand, the female respondents preferred TV compared to male respondents. Age and religion were not associated with the main source of COVID 19 information. See Table 4.

Table 4

Socio demographic factors by sources of COVID 19 Information

\begin{tabular}{|c|c|c|c|c|c|c|c|}
\hline Variable & $\begin{array}{l}\text { Community } \\
\text { Meeting } \\
\mathrm{n}(\%)\end{array}$ & $\begin{array}{l}\text { IEC } \\
\text { Materials } \\
\text { from } \\
\text { MOH } \\
\text { n (\%) }\end{array}$ & $\begin{array}{l}\text { Radio } \\
\text { n (\%) }\end{array}$ & $\begin{array}{l}\text { Social } \\
\text { Media } \\
\mathrm{n}(\%)\end{array}$ & $\begin{array}{l}\text { TV } \\
\mathrm{n}(\%)\end{array}$ & $\begin{array}{l}\text { Word of } \\
\text { Mouth } \\
n(\%)\end{array}$ & $\begin{array}{l}\text { P- } \\
\text { Value(Cramer's } \\
\text { V) }\end{array}$ \\
\hline Age & $2(0.54)$ & $4(1.09)$ & $90(24.46)$ & 147(39.95) & $119(32.34)$ & $6(1.63)$ & \multirow[t]{3}{*}{0.905} \\
\hline 18 to 23 years & $1(0.40)$ & $4(1.61)$ & $59(23.69)$ & $100(40.16)$ & $75(30.12)$ & $10(4.02)$ & \\
\hline $\begin{array}{l}24 \text { to } 29 \text { years } \\
30-35 \text { years }\end{array}$ & $0(0.00)$ & $1(2.08)$ & $10(20.83)$ & $21(43.75)$ & $15(31.25)$ & $1(2.08)$ & \\
\hline $\begin{array}{l}\text { Gender } \\
\text { Female }\end{array}$ & $\begin{array}{l}0(0.00) \\
3(0.75)\end{array}$ & $\begin{array}{l}6(2.33) \\
3(0.75)\end{array}$ & $\begin{array}{l}41(15.89) \\
116(29.93)\end{array}$ & $\begin{array}{l}105(40.70) \\
160(39.90)\end{array}$ & $\begin{array}{l}96(37.21) \\
112(27.93)\end{array}$ & $\begin{array}{l}10(3.88) \\
7(1.75)\end{array}$ & \multirow[t]{2}{*}{$\begin{array}{l}0.007 * * * \\
(0.1348)\end{array}$} \\
\hline $\begin{array}{l}\text { Male } \\
\text { Prefer not to say }\end{array}$ & $0(0.00)$ & $0(0.00)$ & $2(33.33)$ & $3(50.00)$ & $1(16.67)$ & $0(0.00)$ & \\
\hline Religion & $2(0.69)$ & $4(1.38)$ & $74(25.61)$ & 108(37.37) & $95(32.87)$ & $6(2.08)$ & \multirow[t]{4}{*}{0.959} \\
\hline Catholic & $0(0.0)$ & $0(0.00)$ & $2(13.33)$ & $8(53.33)$ & $4(26.67)$ & $1(6.67)$ & \\
\hline Islam & $0(0.0)$ & $0(0.00)$ & $1(33.33)$ & $2(66.67)$ & $0(0.00)$ & $0(0.00)$ & \\
\hline $\begin{array}{l}\text { No Religion } \\
\text { Protestant }\end{array}$ & $1(0.28)$ & $5(1.40)$ & $82(22.91)$ & $150(41.90)$ & $110(30.73)$ & $10(2.79)$ & \\
\hline $\begin{array}{l}\text { Education Level } \\
\text { College/university }\end{array}$ & $\begin{array}{l}3(0.72) \\
0(0.00)\end{array}$ & $\begin{array}{l}7(1.67) \\
0(0.00)\end{array}$ & $\begin{array}{l}80(19.14) \\
10(52.63)\end{array}$ & $\begin{array}{l}188(44.98) \\
4(21.05)\end{array}$ & $\begin{array}{l}127(30.38) \\
5(26.32)\end{array}$ & $\begin{array}{l}13(3.11) \\
0(0.00)\end{array}$ & \multirow[t]{2}{*}{$\begin{array}{l}0.004 * * * \\
(0.1402)\end{array}$} \\
\hline $\begin{array}{l}\text { Secondary } \\
\text { Primary }\end{array}$ & $0(0.00)$ & $2(0.88)$ & $69(30.26)$ & 76(33.33) & 77(33.77) & $4(1.75)$ & \\
\hline County Category & $0(0.0)$ & $2(1.11)$ & $56(31.11)$ & $59(32.78)$ & $61(33.89)$ & $2(1.11)$ & \multirow{3}{*}{$\begin{array}{l}0.006 * \star * \\
(0.1364)\end{array}$} \\
\hline Peri Urban & $1(0.54)$ & $2(1.08)$ & $55(29.57)$ & $69(37.10)$ & $53(28.49)$ & $6(3.23)$ & \\
\hline Rural Counties & $2(0.67)$ & $5(1.67)$ & $48(16.05)$ & $140(46.82)$ & $95(31.77)$ & $9(3.01)$ & \\
\hline
\end{tabular}

Multinomial logistic regression was carried out to determine significant predictors in gender, religion, level of education and county of residence; the 'Male' predictor was positive and significant $(b=.5737$, s.e. $=.2267 p=.011)$. This predictor revealed that the male youths were more likely to access information on COVID-19 vaccine on radio and less likely on social media as compared to female. 
Both primary and secondary predictors were positive and significant $(b=1.7472$, s.e. $=.6260 p=.005),(b=0.7232$, s.e. $=.2183 p=.0 .001)$ respectively. The positive slope suggests that the youth participants with primary and secondary level of education are more likely to access information on COVID 19 on Radio and less likely on social media as compared to participants with tertiary/ University level of education. Comparing the accessibility of COVID 19 information on TV and social media, participants with secondary level of education were more likely to access information on COVID 19 on TV and less likely on social media.

The 'urban category' predictor was negative and significant $(b=-0.9023$, s.e. $=.2517 p=.00)$, The negative slope indicates that participants from urban counties were less likely to access information on COVID 19 on Radio and more likely to access the same information on social media as compared with participants from rural counties. See table 5.

Disaggregating by education level, the youths with primary level of education relied on radio as the source of COVID 19 information. The rural youth with primary level of education depicted the highest dependence on radio as the source of information. On the other hand, the youths with college/university level of education relied majorly on social media, the youths residing in urban counties and with college/university level of education depicted the highest dependence on social media as the source of information on COVID 19. See Fig. 9.

Table 5: Multinomial logistic regression on socio demographic factors and vaccine uptake

\begin{tabular}{|c|c|c|c|c|c|c|}
\hline \multirow[t]{2}{*}{ Sources of Information } & \multicolumn{3}{|l|}{ Radio } & \multicolumn{3}{|l|}{ TV } \\
\hline & Coefficient & Standard error & P-value & Coefficient & Standard error & P-value \\
\hline Gender & 0.5737 & .2268706 & 0.011 & -.2882506 & .1890588 & 0.127 \\
\hline Female & .439246 & .9793025 & 0.654 & -1.037774 & 1.174332 & 0.377 \\
\hline \multicolumn{7}{|l|}{ Male } \\
\hline \multicolumn{7}{|l|}{ Prefer not to say } \\
\hline Education Level & 1.7470 & 0.6260 & 0.005 & 0.6596 & 0.6872 & 0.337 \\
\hline University/Tertiary & 0.7232 & 0.2183 & 0.001 & 0.4119 & 0.1998 & $0.039 * \star *$ \\
\hline \multicolumn{7}{|l|}{ Primary } \\
\hline \multicolumn{7}{|l|}{ Secondary } \\
\hline Urban_Category & 0.08369 & 0.2665 & 0.753 & 0.2755 & 0.2600 & 0.289 \\
\hline Rural & -0.9023 & 0.2518 & $0.000 * * *$ & -0.1322 & 0.2274 & 0.561 \\
\hline \multicolumn{7}{|l|}{ Peri urban } \\
\hline urban & & & & & & \\
\hline
\end{tabular}

Similarly, the male youths with primary level of education majorly depend on radio as the source of COVID 19 information compared to female with same level of education. There was no substantial difference on the reliance on social media across the gender. Female with secondary level of education relied on majorly on TV as the source of information on COVID 19 compared with female with same level of education. See Fig. 10.

$60.33 \%$ of the youths feel that the information on COVID 19 is being shared openly, a chi square test revealed that there a relationship between the uptake of COVID 19 vaccine and the feeling that the information on vaccine was being shared openly (Chi square P Value $0.001<0.05$ at $95 \%$ C.I) and the association. 
Despite the fact that majority of the respondents believe that the information is being shared openly the youths believe that these information is not sufficient see Fig. 9 above. Furthermore, $55.32 \%$ of the youth have heard information on social media that will make them reconsider the uptake of COVID 19 vaccine and the relationship with uptake of COVID 19 vaccine was statistically significant (Chi square $P$ Value $0.005<0.05$ at $95 \%$ C.I).

Majority of the youths surveyed thinks that political leader's sentiments on COVID-19 vaccine can trigger doubts on the vaccine amongst the youths/ the community, this factor showed a statistically significant relationship with the uptake of COVID 19 Vaccine (Chi square P Value $0.005<0.05$ at $95 \%$ C.I). There was no relationship between the uptake of vaccine and culture. See Table 6.

Multinomial logistic regression was carried out to determine significant predictors in the uptake of COVID 19 vaccine. The 'Do you feel that information on COVID 19 vaccine is being openly shared' predictor is negative and significant $(b=-2.4899$, s.e. $=.4183, p=0.000)$. This suggests that participants who feel that information on COVID 19 vaccine is being shared openly are more likely to get vaccinated and more likely to be the first people to get vaccinated as compared to participants who feel that information on COVID 19 vaccine is not shared openly. They are also less likely to wait and see how people react to the vaccine. $(b=-12788$, s.e. $=.1880, p=0.000)$.

Table 6

Contextual Influences by intention to get COVID-19 vaccine

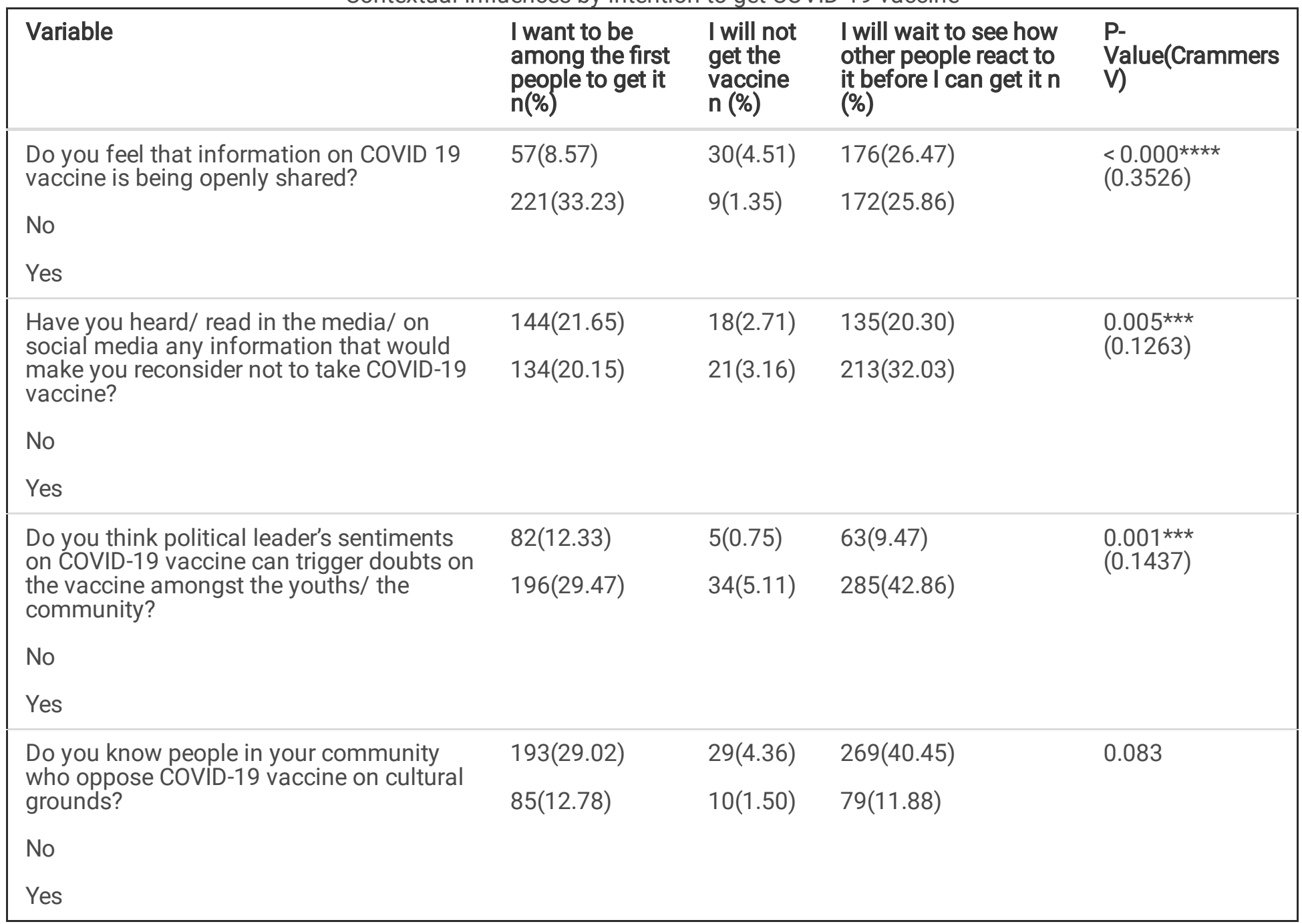

base outcome is "I want to be among the first people to get the Vaccine 
Looking at 'Have you heard/ read in the media/ on social media any information that would make you reconsider not to take COVID-19 vaccine' and the uptake of CIVID 19 vaccine, this predictor is positive and significant $(b=0.3744$, s.e. $=.0 .1714, p=.0 .029)$. This indicates that participants who have heard/ read in the social media any information that would make them reconsider not to take COVID-19 vaccine are more likely to wait to see how other people react to it before they can get it and less likely to be among the first people to get vaccinated as compared to those who had not heard/ read in the media/ on social media any information that would make them reconsider not to take COVID-19 vaccine. See Table 7.

Table 7

Multinomial logistic regression on socio Contextual Influences and vaccine uptake

\begin{tabular}{|c|c|c|c|c|c|c|}
\hline \multirow[t]{2}{*}{ Variable } & \multicolumn{3}{|c|}{ I will not get the vaccine $\mathrm{n}(\%)$} & \multicolumn{3}{|c|}{$\begin{array}{l}\text { I will wait to see how other people } \\
\text { react to it before I can get it n (\%) }\end{array}$} \\
\hline & Coefficient & $\begin{array}{l}\text { Standard } \\
\text { error }\end{array}$ & P-value & Coefficient & $\begin{array}{l}\text { Standard } \\
\text { error }\end{array}$ & P-value \\
\hline $\begin{array}{l}\text { Do you feel that information on COVID } 19 \\
\text { vaccine is being openly shared? }\end{array}$ & -2.4899 & 0.4183 & $0.000 * \star \star$ & -1.2788 & 0.1880 & $0.000 * \star *$ \\
\hline \multicolumn{7}{|l|}{ Reference Predictor-No } \\
\hline \multicolumn{7}{|l|}{ Yes } \\
\hline $\begin{array}{l}\text { Have you heard/ read in the media/ on } \\
\text { social media any information that would } \\
\text { make you reconsider not to take COVID-19 } \\
\text { vaccine? }\end{array}$ & -0.6106 & 0.3594 & 0.865 & 0.3744 & 0.1714 & $0.029 * * *$ \\
\hline \multicolumn{7}{|l|}{ Reference Predictor-No } \\
\hline \multicolumn{7}{|l|}{ Yes } \\
\hline $\begin{array}{l}\text { Do you think political leader's sentiments } \\
\text { on COVID- } 19 \text { vaccine can trigger doubts } \\
\text { on the vaccine amongst the youths/ the } \\
\text { community? }\end{array}$ & 0.4130 & 0.5218 & 0.429 & 0.2982 & 0.2026 & 1.47 \\
\hline \multicolumn{7}{|l|}{ Reference Predictor-No } \\
\hline Yes & & & & & & \\
\hline
\end{tabular}

Sharing of relevant vaccine information is key and the youths surveyed reported that the most trusted source of information was health care providers $26.32 \%$ followed by TV and Radio at $20.66 \%$ and $18.59 \%$ respectively and the least trusted source of information was word of mouth 55.19\%. See Fig. 11.

\section{Individual and Group Influences}

The study revealed that majority of the youths $30.73 \%$ reported to influence their parents or the vulnerable groups not to receive the vaccine at an average extent. See Fig. 13.

$64.21 \%$ of the youths surveyed believe that once there were vaccinated with COVID-19 vaccine, other people in the community will be protected as well. A statistically significant relationship was obtained between 'do you believe that once you are vaccinated with COVID-19 vaccine, other people in the community will be protected as well believe that once you are vaccinated with COVID-19 vaccine, other people in the community will be protected as well' and uptake of COVID 19 vaccine (Chi square $P$ Value $0.000<0.05$ at $95 \%$ C.I). The study further showed that $71.72 \%$ of the youth support mass vaccination, this was also statistically significant (Chi square P Value $0.000<0.05$ at $95 \%$ C.I) and the association is moderate .See Table 8. 
Table 8

Group influences by intention to get COVID-19 vaccine

\begin{tabular}{|c|c|c|c|c|}
\hline Variable & $\begin{array}{l}\text { I want to be } \\
\text { among the first } \\
\text { people to get it } \\
\mathrm{n}(\%)\end{array}$ & $\begin{array}{l}\text { I will not } \\
\text { get the } \\
\text { vaccine n } \\
(\%)\end{array}$ & $\begin{array}{l}\text { I will wait to see how } \\
\text { other people react to it } \\
\text { before I can get it } n \\
(\%)\end{array}$ & $\begin{array}{l}\text { P- } \\
\text { Value(Crammers } \\
\text { V) }\end{array}$ \\
\hline \multirow{2}{*}{$\begin{array}{l}\text { Do you believe that once you are } \\
\text { vaccinated with COVID-19 vaccine, other } \\
\text { people in the community will be } \\
\text { protected as well? }\end{array}$} & $66(9.92)$ & $28(4.21)$ & $144(21.65)$ & \multirow{4}{*}{$\begin{array}{l}P<0.000 \star \star \star \star \\
(0.2581)\end{array}$} \\
\hline & $212(31.88)$ & 11(1.65) & $204(30.68)$ & \\
\hline \multicolumn{4}{|l|}{ No } & \\
\hline \multicolumn{4}{|l|}{ Yes } & \\
\hline \multirow{2}{*}{$\begin{array}{l}\text { Do you support mass vaccination } \\
\text { (vaccinating everyone) with COVID-19 } \\
\text { vaccine? }\end{array}$} & $27(4.06)$ & $32(4.81)$ & $129(19.40)$ & \multirow{2}{*}{$\begin{array}{l}<0.001 \star \star \star \star \\
(0.4179)\end{array}$} \\
\hline & 251(37.74) & $7(1.05)$ & $219(32.93)$ & \\
\hline \multicolumn{5}{|l|}{ No } \\
\hline Yes & & & & \\
\hline
\end{tabular}

Multinomial logistic regression to determine youths uptake of COVID 19 vaccine, the study revealed that the youths believe that once they are vaccinated with COVID-19 vaccine, other people in the community will be protected as well' are more likely to get vaccinated $(b=-1.4466$, s.e. $=.0 .4085, p=.0 .000)$ and less likely to wait and see how people react to the vaccine before they can get it ( $b=-05585$, s.e. $=.1882, p=.0 .003)$ as compared to those who do not believe that once you are vaccinated with COVID-19 vaccine, other people in the community will be protected as well.

In addition the youths who support mass vaccination (vaccinating everyone) with COVID-19 vaccine are more likely to be among the first people to get vaccinated $(b=-3.4201$, s.e. $=0.4728, p=.0 .000)$ and are less likely to wait and see how people react to the vaccine before they can get it $(b=-1.5765$, $s . e=0.2347, p=0.000)$ as compared to those who do not support mass vaccination (vaccinating everyone) with COVID-19 vaccine. See Table 9.

Table 9

Multinomial logistic regression on Individual and Group Influences and vaccine uptake Vaccine safety and vaccination specific Determinants

\begin{tabular}{|c|c|c|c|c|c|c|}
\hline \multirow[t]{2}{*}{ Variable } & \multicolumn{3}{|c|}{ I will not get the vaccine $n(\%)$} & \multicolumn{3}{|c|}{$\begin{array}{l}\text { I will wait to see how other people } \\
\text { react to it before I can get it n (\%) }\end{array}$} \\
\hline & Coefficient & $\begin{array}{l}\text { Standard } \\
\text { error }\end{array}$ & P-value & Coefficient & $\begin{array}{l}\text { Standard } \\
\text { error }\end{array}$ & P-value \\
\hline $\begin{array}{l}\text { Do you believe that once you are } \\
\text { vaccinated with COVID- } 19 \text { vaccine, other } \\
\text { people in the community will be protected } \\
\text { as well? }\end{array}$ & -1.4466 & 0.4085 & $0.000 * \star \star$ & -0.5585 & 0.1882 & $0.003^{* \star *}$ \\
\hline \multicolumn{7}{|l|}{ Reference Predictor-No } \\
\hline \multicolumn{7}{|l|}{ Yes } \\
\hline $\begin{array}{l}\text { Do you support mass vaccination } \\
\text { (vaccinating everyone) with COVID-19 } \\
\text { vaccine? }\end{array}$ & -3.4201 & 0.4728 & $0.000^{\star \star *}$ & -1.5765 & 0.2347 & $0.000 * * *$ \\
\hline \multicolumn{7}{|l|}{ Reference Predictor-No } \\
\hline Yes & & & & & & \\
\hline
\end{tabular}


$59.99 \%$ of the youths surveyed believe that our Country is not able to manage risks associated with COVID-19 vaccine side effects, a chi square test was carried out to determine if this relationship with uptake of COVID 19 vaccine was significant a $P$ Value $=0.000<0.05$ at $95 \%$ C.I was obtained. This implies that there is a relationship between country's readiness to manage the risk associate with COVID 19 vaccine and the uptake of the vaccine is statistically significant. Moreover, majority $35.73 \%$ of the youths are somewhat confident on the safety of CIVID 19 vaccine and this relationship with the uptake of vaccine was found to be statistically significant with $\mathrm{P}$ Value $=0.000<0.05$ at $95 \% \mathrm{C}$.I and the association was high. In addition, majority $29.78 \%$ are concerned that they can develop serious side effects from the COVID-19 vaccine, the relationship with uptake of COVID 19 vaccine was statistically significant with $P$ Value $=0.000<0.05$ at $95 \%$ C.I. On the other hand, $78.65 \%$ of the youths trust the health system to deliver COVID-19 vaccine to their communities and somewhat agree that the benefits of being vaccinated with COVID-19 vaccine exceeds the risks of not being vaccinated. These relationships were statistically significant with (chi-square test $\mathrm{P}$-value $=0.00<0.05,95 \% \mathrm{Cl}$ ) and (chi-square test, $\mathrm{P}$-value $=$ $0.00<0.05,95 \% \mathrm{Cl}$ ) respectively. See Table 10 . 
Table 10

Vaccine safety and vaccination specific Determinants

\begin{tabular}{|c|c|c|c|c|c|}
\hline Question asked & Answer & $\begin{array}{l}\text { I want to be } \\
\text { among the } \\
\text { first people } \\
\text { to get it } n(\%)\end{array}$ & $\begin{array}{l}\text { I will not } \\
\text { get the } \\
\text { vaccine } \\
\text { n (\%) }\end{array}$ & $\begin{array}{l}\text { I will wait to see } \\
\text { how other people } \\
\text { react to it before I } \\
\text { can get it } n(\%)\end{array}$ & $\begin{array}{l}\text { P- } \\
\text { Value(Crammers } \\
\text { V) }\end{array}$ \\
\hline \multirow{2}{*}{$\begin{array}{l}\text { Do you feel our country is able to } \\
\text { manage risks associated with } \\
\text { COVID-19 vaccine side effects? }\end{array}$} & No & 115(17.29) & $30(4.51)$ & 234(35.19) & \multirow{2}{*}{$\begin{array}{l}<0.000 * \star \star \\
(0.2712)\end{array}$} \\
\hline & Yes & 163(24.51) & $9(1.35)$ & 114(17.14) & \\
\hline \multirow{2}{*}{$\begin{array}{l}\text { Can the health system be trusted to } \\
\text { deliver COVID-19 vaccine to your } \\
\text { communities? }\end{array}$} & No & 26(3.91) & 21(3.16) & $95(14.29)$ & \multirow{2}{*}{$\begin{array}{l}<0.000 * * * \\
(0.2894)\end{array}$} \\
\hline & Yes & 252(37.89) & $18(2.71)$ & 253(38.05) & \\
\hline \multirow{7}{*}{$\begin{array}{l}\text { How confident are you in the safety } \\
\text { of COVID- } 19 \text { vaccine? }\end{array}$} & \multirow{2}{*}{$\begin{array}{l}\text { Very } \\
\text { confident }\end{array}$} & 113(16.99) & $3(0.45)$ & $28(4.21)$ & \multirow{7}{*}{$\begin{array}{l}<0.000 * \star \star \\
(0.4853)\end{array}$} \\
\hline & & $90(13.53)$ & $3(0.45)$ & $53(7.97)$ & \\
\hline & Confident & 65(9.77) & $2(0.30)$ & 168(25.26) & \\
\hline & $\begin{array}{l}\text { Somehow } \\
\text { confident }\end{array}$ & $7(1.05)$ & $13(1.95)$ & 67(10.08) & \\
\hline & \multirow{2}{*}{$\begin{array}{l}\text { Not } \\
\text { confident } \\
\text { Not } \\
\text { confident } \\
\text { at all }\end{array}$} & $0(0.00)$ & $15(2.26)$ & $14(2.21)$ & \\
\hline & & $3(0.45)$ & $3(0.45)$ & 18(2.71) & \\
\hline & $\begin{array}{l}\text { Don't } \\
\text { know }\end{array}$ & & & & \\
\hline \multirow{2}{*}{$\begin{array}{l}\text { Do you remember any vaccine } \\
\text { associated health problems in the } \\
\text { past that may prevent you from } \\
\text { getting the COVID-19 vaccine? }\end{array}$} & No & 228(34.29) & $27(4.06)$ & 281(42.26) & \multirow[t]{2}{*}{0.167} \\
\hline & Yes & $50(7.52)$ & $12(1.80)$ & $67(10.08)$ & \\
\hline \multirow{6}{*}{$\begin{array}{l}\text { How concerned are you that you } \\
\text { can develop serious side effects } \\
\text { from the COVID-19 vaccine? }\end{array}$} & Don't & $29(4.36)$ & $4(0.60)$ & $29(4.36)$ & \multirow{6}{*}{$\begin{array}{l}<0.000 * \star \star \\
(0.2942)\end{array}$} \\
\hline & NrIOW & 71(10.53) & $1(0.15)$ & $19(2.86)$ & \\
\hline & Not at all & $81(12.18)$ & $1(0.15)$ & 73(10.98) & \\
\hline & $\begin{array}{l}\text { Not too } \\
\text { much }\end{array}$ & $54(8.12)$ & $5(0.75)$ & 101(15.19) & \\
\hline & Somewhat & $44(6.62)$ & $28(4.21)$ & 126(18.95) & \\
\hline & Very Much & & & & \\
\hline \multirow{5}{*}{$\begin{array}{l}\text { How much do you agree that } \\
\text { benefits of being vaccinated with } \\
\text { COVID- } 19 \text { vaccine exceeds the risks } \\
\text { of not being vaccinated? }\end{array}$} & Strongly & $84(12.63)$ & $6(0.90)$ & $43(6.47)$ & \multirow{5}{*}{$\begin{array}{l}<0.000 \star \star \star \\
(0.2321)\end{array}$} \\
\hline & & $58(8.72)$ & $2(0.30)$ & 78(11.73) & \\
\hline & & $53(7.97)$ & $7(1.05)$ & 128(19.25) & \\
\hline & Neutral & $37(5.56)$ & $11(1.65)$ & $66(9.92)$ & \\
\hline & $\begin{array}{l}\text { Strongly } \\
\text { Disagree }\end{array}$ & $46(6.92)$ & 13(1.95) & $33(4.96)$ & \\
\hline
\end{tabular}

Multinomial logistic regression was carried out to determine significant predictors in the uptake of COVID 19 vaccine. The 'Can the health system be trusted to deliver COVID-19 vaccine to your communities?' predictor is negative and significant $(b=-1.4831$, s.e. $=.4866, p=.0 .002)$. The negative slope indicates that participants who trust that the health system can deliver COVID-19 vaccine to their communities are more likely to get vaccinated and less likely to wait and see how people 
react to the vaccine before they can get it $(b=-0.5388$, s.e. $=.2745, p=.0 .050)$ as compared to those who do trust that the health system to deliver COVID-19 vaccine to their communities.

The 'How confident are you in the safety of COVID-19 vaccine?' predictor is positive and significant $(b=3.4989$, s.e. $=.7926$, $p=.000$ ). The positive slope indicates that participants who are not confident in the safety of COVID-19 vaccine are more likely not to get vaccinated and more likely to wait and see how people react to the vaccine before they can get it $(b=$ 2.4461 , s.e. $=.44565, p=.0 .000$ ) as compared to those who are confident in the safety of COVID-19 vaccine.

The 'How much do you agree that benefits of being vaccinated with COVID-19 vaccine exceeds the risks of not being vaccinated?' predictor is positive and significant $(b=1.7319$, s.e. $=.0 .8850, p=.0 .050)$. The positive slope indicates that participants who strongly disagree that benefits of being vaccinated with COVID-19 vaccine exceeds the risks of not being vaccinated are more likely not to get vaccinated and less likely to be among the first people to get vaccinated as compared to those who strongly agree that benefits of being vaccinated with COVID-19 vaccine exceeds the risks of not being vaccinated. See Table 11. 
Table 11

Multinomial logistic regression on Vaccine safety and vaccination specific Determinants and vaccine uptake

\begin{tabular}{|c|c|c|c|c|c|c|}
\hline \multirow[t]{2}{*}{ Variable } & \multicolumn{3}{|c|}{ I will not get the vaccine $n(\%)$} & \multicolumn{3}{|c|}{$\begin{array}{l}\text { I will wait to see how other people } \\
\text { react to it before I can get it } n(\%)\end{array}$} \\
\hline & Coefficient & $\begin{array}{l}\text { Standard } \\
\text { error }\end{array}$ & P-value & Coefficient & $\begin{array}{l}\text { Standard } \\
\text { error }\end{array}$ & P-value \\
\hline $\begin{array}{l}\text { Do you feel our country is able to } \\
\text { manage risks associated with COVID-19 } \\
\text { vaccine side effects? }\end{array}$ & -0.4284 & 0.5174 & 0.408 & -0.3836 & 0.2034 & 0.059 \\
\hline \multicolumn{7}{|l|}{ Reference Predictor-No } \\
\hline \multicolumn{7}{|l|}{ Yes } \\
\hline $\begin{array}{l}\text { Can the health system be trusted to } \\
\text { deliver COVID-19 vaccine to your } \\
\text { communities? }\end{array}$ & -1.4831 & 0.4866 & $0.002^{\star \star \star}$ & -0.5388 & 0.2745 & $0.050 \star \star \star *$ \\
\hline \multicolumn{7}{|l|}{ Reference Predictor-No } \\
\hline \multicolumn{7}{|l|}{ Yes } \\
\hline \multirow{2}{*}{$\begin{array}{l}\text { How confident are you in the safety of } \\
\text { COVID-19 vaccine? }\end{array}$} & -0.3256 & 0.8549 & 0.703 & -0.7059 & 0.2872 & $0.014^{\star \star \star}$ \\
\hline & -0.2544 & 0.9400 & 0.787 & 1.3098 & 0.2345 & $0.000 * * *$ \\
\hline Reference Predictor- Confident & 3.4989 & 0.7926 & $0.000 * \star \star$ & 2.4461 & 0.4456 & $0.000 * \star \star *$ \\
\hline \multirow{4}{*}{$\begin{array}{l}\text { Somehow confident } \\
\text { Not confident } \\
\text { Not confident at all } \\
\text { Don't know }\end{array}$} & 18.0808 & 585.3956 & 0.975 & 15.6067 & 585.3953 & 0.979 \\
\hline & 3.5272 & 1.0341 & 0.001 & 2.1140 & 0.6583 & $0.001 * * *$ \\
\hline & & & & & & \\
\hline & & & & & & \\
\hline \multirow{3}{*}{$\begin{array}{l}\text { How much do you agree that benefits of } \\
\text { being vaccinated with COVID-19 vaccine } \\
\text { exceeds the risks of not being } \\
\text { vaccinated? }\end{array}$} & 0.7667 & 0.9146 & 0.402 & -0.5532 & 0.2906 & 0.057 \\
\hline & 0.3004 & 0.8795 & 0.733 & 0.2830 & 0.302 & 0.302 \\
\hline & 1.6277 & 0.8706 & 0.062 & 0.4772 & 0.3093 & 0.123 \\
\hline Strongly Agree & \multicolumn{6}{|c|}{ Neutral } \\
\hline \multicolumn{7}{|l|}{ Disagree } \\
\hline Strongly Disagree & & & & & & \\
\hline
\end{tabular}

Vaccine Knowledge Questions

Majority of the respondents $86.17 \%$ do not know what the COVID-19 vaccine contains and $46.92 \%$ of them do not know the effectiveness of COVID-19 vaccines in preventing infection as shown in Table 12 


\begin{tabular}{|lll|}
\hline Variable & Frequency & Percent(\%) \\
\hline Do you know what the COVID-19 vaccine contains? & 573 & 86.17 \\
No & 92 & 13.1 .83 \\
Yes & & \\
\hline Do you know the effectiveness of COVID-19 vaccines in preventing infection? & 226 & 33.98 \\
a. Is quite high in vaccines that have been approved & 127 & 19.10 \\
b. It will be known once the COVID-19 vaccines are in use for a while & 312 & 46.92 \\
c. I do not know & & \\
\hline
\end{tabular}

\section{Discussions}

\section{Behavior intetions}

The youth are aware of the benefits of the vaccine but worry about the effect it could have on their health. Those who are ready to be vaccinated immediately stands at $42 \%, 60 \%$ of them believed that their relatives and friends are ready to be vaccinated and $71 \%$ support for their community to have mass vaccination. As a result, $52 \%$ of youth are not ready to be vaccinated and are waiting to see what happens to those who have received the vaccine while $6 \%$ are totally unwilling. Therefore, total COVID 19 vaccine hesitancy stands at $58 \%$.

During the discussion with the youth it was established that the major cause of hesitancy among the youth was fear: fear of the unknown or the uncertainty associated with the COVID vaccine. The fear of the long term effects on their bodies such as losing their body functionality seemed to stand out: "... you're thinking at my age, if this thing can affect me, then, how will my tomorrow be, will I get to a place where, I can only have one child, will I get to a place where I cannot you know, be able to function like I would have done if I had stayed without the vaccine..." and "... what if I get and then I start developing some condition afterwards?". This fear is also tied to that which concerns fear of uncertainty over the body's potential adverse reactions to the vaccine such as fever, headaches, migraines, joint pains, absence of menses. Some of those heard of include: blood clots, infertility in men and changing the women's menstrual cycle, including missing monthly periods.

\section{Attitude: Contextual Influences - communication and social media, gender and socio-cultural}

The most common source of information about COVID-19 vaccines was reliance on social media where $60.33 \%$ of the youths feel that the information on COVID 19 is being shared openly. The study further revealed that male youths are likely to access information from radio more than from social media compared to females, youths with primary level of education are also likely to access information from radio more than social media compared to those with post-secondary education while those with secondary education likely to access information from radio and TV than from social media compared to those with post-secondary education. Youths living in urban areas are likely to access information on social media than radio compared to youths living in rural.

Despite the fact that majority of the respondents believe that the information is being shared openly the youths believe that these information is not sufficient. Furthermore, $55.32 \%$ of the youth have heard information on social media that will make them reconsider the uptake of COVID 19 vaccine and the relationship with uptake of COVID 19 vaccine.

In the focus group discussion it was also established that there is a lot of COVID related information that the youth are able to access and it is hard to know what is right and what is wrong. The sources of this information are mainly: the social 
media, peers, neighbors in the community and church leaders among others. Alongside this is also information that is not clear on the benefits and side effects of the vaccine; duration of efficiency as well as which vaccine is best for us in this part of the world. Promotion of memes and other short messaging that can be passed through social media aimed at promoting vaccine uptake among the youths.

The Ministry of Health is also not using as much effort to encourage uptake of the vaccine as it did with telling people about the COVID protocols or when giving COVID related statistics. At the same time, some of this information is also contradictory and the experts' voice has not been heard loudly enough ascertaining the facts - giving grounds for myths and controversy theories to abound.

The internet and social media is littered with lots of controversial videos on the COVID vaccine. These include things such as it being a way to introduce microchips and other tracking devices into our bodies, a biotechnology weapon being used as a channel to kill Africans - being favored by the introduction of the $5 \mathrm{G}$ network and it being a form of antichrist (666) and association with the devil. The tracking or monitoring devices are believed to be one of the steps towards a new world order which would aim at controlling people too. Others have wondered why the vaccines are being forcibly introduced in Africa while the heavier brunt was in the European countries.

\section{Attitude: Individual and Group Influences}

The study revealed that majority of the youths support mass vaccination while $64.21 \%$ believe that once there are vaccinated with COVID-19 vaccine, other people in the community will be protected as well.

During the focus group discussion it was clear that majority of the youth supports the use of mass awareness campaigns as lack of education is the biggest problem. There is need for people to be more informed on factual information. Peer education therefore becomes a critical tool. The government should also consider setting up more vaccine centres for the provision of vaccine services closer to the youth and even consider a door to door programme if possible. A belief which appeared to be very common among the youth was that the youth have some level of immunity against the virus resulting in hesitance in uptake of the vaccine.

\section{Attitude: Vaccine safety and vaccination specific Determinants}

The youths surveyed believe that our country is not able to manage risks associated with COVID-19 vaccine side effects. The youths are somewhat confident on the safety of COVID 19 vaccine and are concerned that they can develop serious side effects from the COVID-19 vaccine. Most of the youths trust the health system to deliver COVID-19 vaccine to their communities and somewhat agree that the benefits of being vaccinated with COVID-19 vaccine exceeds the risks of not being vaccinated.

The focused group discussions brought out myths which target women that the vaccine could be more harmful after taking it compared to when not taken, hence the hesitancy among women. Women feel that their bodies are more complicated than men and need to be protected from any complications associated with the vaccine, and since men's body is not complicated, they can risk to get the vaccine.

\section{Vaccine knowledge}

Majority of the youths do not know what the COVID-19 vaccine contains and most of them do not know the effectiveness of COVID-19 vaccines in preventing infection.

The discussion with the youth revealed that youth's belief that the COVID vaccine does not seem to work. Another belief was that the COVID vaccine was to be a tool to help control the population by affecting one's DNA and reducing ability to reproduce. This is a belief which strongly resonated among the youth from both rural and urban setting and seemed to be 
supported by those who had heard of one of the side effects of the vaccine being Amenorrhea. At the same time, it is actually believed to be having family planning medication as one of its constituents. Another popular belief among the youth was that the vaccine weakened one's immunity making one susceptible to other diseases and could even cause death

\section{Conclusion}

The Vaccine hesitancy among the youth is at $58 \%$. The major determinants for their uptake of the vaccine were: fear of the unknown; fear of losing functionality of their bodies once they receive the vaccine; concerns around safety and effectiveness of the COVID-19 vaccine; concerns about the adverse effects of the vaccine to the body such as fever, headaches, migraines, joint pains, absence of menses. Some of those heard of include: blood clots, infertility in men and changing the women's menstrual cycle, including missing monthly periods; and lack of right information. Most youths felt that COVID-19 vaccine information was openly shared with social media being the main source of information for youths. However, social media was identified as a contributor of vaccine hesitancy among the youths. Other determinants of COVID-19 vaccine hesitancy among the youths included low trust in the ministry of health, belief that mass vaccination was not helpful.

Many youths did not know the what the vaccine contains, and did not believe that the vaccine was effective in curing the COVID-19 disease. some of the youths belived that the vaccine does not work, others believed it was aconspiracy to control the population. Other youths believed it caused deaths, and this contributed to the increased level of vaccine hesitancy among the youths.

\section{RECOMMENDATIONS}

1. Design and implement a communication strategy on COVID vaccine to provide accurate information to the youth

2. COVID vaccine rollout should take into account the contextual gender disparities and should ensure that women are not left out

3. Work with protestant religious leaders more to reduce hesitancy among their flock

4. Work to improve trust in $\mathrm{MoH}$ to enhance their leadership in the vaccination drive

\section{Abbreviations}

COVID-19 Coronavirus disease 2019

ETPB Extended Theory of Planned Behaviour

NBCC The National Business compact on Corona

SARS-Cov-2 Severe acute respiratory syndrome coronavirus 2

SPSS Statistical Package for Social Sciences

TPB Theory of Planned Behavior

WHO World Health Organization

\section{Declarations}

\section{Ethics approval and consent to participate}


The ESRC of Amref Health Africa gave the approval of the research protocol. Approval to carry out the study was sought from NACOSTI. The participants were requested to sign an online informed consent before starting the online survey. The website was secured with a strong password which was provided to the study participants, research facilitators, and the team that carried out the study. The research administrators submitted the online filled questionnaires to the servers, which was only accessible by them. The focused group discussion recordings were secured with a password until data analysis was completed, and then the recordings were discarded following ESRC guidelines. The participants were not allowed to use their names on the questionnaires; instead, they used codes to enhance anonymity. Codes were used instead of participants' names on the questionnaire to ensure anonymity. The staff with access to login details of the website and the server administrators were required to sign a Confidentiality Agreement at the commencement of the study.

\section{Consent for publication}

All the authors gave their consent for the manuscript to be published.

\section{Availability of data and materials}

The data included in this manuscript were as collected from the respondents and analysed without alteration for any reason.

\section{Competing interests}

The authors declare that there was no conflict of interest in publication of the manuscript.

\section{Funding}

The research was funded by King Baudouin Foundation United States (KBFUS).

\section{Authors' contributions}

Prof. Joachim Osur: conceptualisation, protocol co-writer, oversight of data collection, analysis, co-writer of the draft manuscript, review and editing of the manuscript, and publishing.

Rehema Chengo Muinde: conceptualisation, designing and writing of the research protocol, data collection, oversight of data management, validation and verification of the data, writing and editing of the manuscript, and publishing

Evelyne Muinga: conceptualisation, designing and writing of the research protocol, data collection, oversight of data management, validation and verification of the data, writing and editing of the manuscript, and publishing.

Jackline Kemboi: methodology, review of the protocol, statistical analysis and validation of the results.

Prof. Myriam Sidibe: review and editing of the protocol, review and editing of the manuscript.

Maggie Rarieya: review and editing of the protocol, review and editing of the manuscript.

\section{ACKNOWLEDGEMENTS}

Special thanks to Amref Health Africa for their support during the study. Specifically, we would like to thank Prof. Joachim Osur, Vice-Chancellor, Amref International University, for providing timely feedback and quality control over the entire study. We thank every team member (Rehema Chengo, Evelyne Muinga, Jackline Kemboi, Prof. Myriam Sidibe, and Maggie Rarieya) for their great contributions during the study and in supporting the entire research process. Special thanks to Josiah Kimanzi who mobilized members in the various digital platforms to take part in the study, and in assistance of Maggie Rarieya and the research team members organized a press conference for dissemination of study findings. the 
team wishes to express their gratitude to Brenda Metobo who assisted in qualitative data collection, analysis of qualitative data, and result dissemination. Our gratitude also goes to the donor King Baudouin Foundation United States (KBFUS) foundation. I would also thank the youth platforms Shujaa Inc Heros4 change, BRCK Moja Y Act and Affluence and their leadership for their participation. I would like to thank everyone who reviewed and participated in one way or another in the guideline development process. Finally, we would like to thank all staff and cooperating partners at national, county, and community levels who aided us during the entire process and made the research possible.

\section{References}

1. Advice to the National Public Health Emergency Team (NPHET). The factors influencing, and measures to improve. vaccination uptake; 2020.

2. Burgess RA, Osborne RH, Yongabi KA, Greenhalgh T, Gurdasani D, Kang G, ... McKee M. The COVID-19 vaccines rush: participatory community engagement matters more than ever. The Lancet. 2021;397(10268):8-10.

3. Detoc M, Bruel S, Frappe P, Tardy B, Botelho-Nevers E, Gagneux-Brunon A. Intention to participate in a COVID-19 vaccine clinical trial and to get vaccinated against COVID-19 in France during the pandemic. Vaccine. 2020;38(45):7002-6.

4. Feemster KA. (2020). Building vaccine acceptance through communication and advocacy.

5. Gadoth A, Halbrook M, Martin-Blais R, Gray AN, Tobin NH, Ferbas KG, ... Rimoin AW. (2020). Assessment of COVID-19 vaccine acceptance among healthcare workers in Los Angeles. medRxiv.

6. Guzman-Holst A, DeAntonio R, Prado-Cohrs D, Juliao P. Barriers to vaccination in Latin America: A systematic literature review. Vaccine. 2020;38(3):470-81.

7. Kennedy J. Vaccine hesitancy: a growing concern. Pediatric Drugs. 2020;22(2):105-11.

8. Larson H, Lee N, Rabin K, Rauh L, Ratzan S. Building Confidence to Convince. Journal of Health Communication; 2021.

9. Lazarus JV, Ratzan SC, Palayew A, Gostin LO, Larson HJ, Rabin K, ... El-Mohandes A. (2020). A global survey of potential acceptance of a COVID-19 vaccine. Nature medicine, 1-4.

10. Malik AA, McFadden SM, Elharake J, Omer SB. (2020). Determinants of COVID-19 vaccine acceptance in the US. EClinicalMedicine, 26, 100495.

11. Puri N, Coomes EA, Haghbayan H, Gunaratne K. (2020). Social media and vaccine hesitancy: new updates for the era of COVID-19 and globalized infectious diseases. Human Vaccines \& Immunotherapeutics, 1-8.

12. Richmond H, Rees N, McHale S, Rak A, Anderson J. (2020). Seasonal influenza vaccination during a pandemic. Human Vaccines \& Immunotherapeutics, 16(9), 2219-2221. Mills, M., Rahal, C., Brazel, D., Yan, J., \& Gieysztor, S. (2020). COVID-19 vaccine deployment: Behaviour, ethics, misinformation and policy strategies. London: The Royal Society \& The British Academy.

13. Sticchi L, Taramasso L, Di Biagio A, Olobardi D, Icardi G, Bassetti M. (2020). Will vaccine hesitancy compromise our efforts to face the next SARS-CoV-2 epidemic wave?. Human Vaccines \& Immunotherapeutics, 1-2.

14. Tam CC, Qiao S, Li X. (2020). Factors associated with decision making on COVID-19 vaccine acceptance among college students in South Carolina. medRxiv.

15. WHO. (2020), Behavioral considerations for acceptance and uptake of COVID-19 vaccines, Accessed at https://apps.who.int/iris/rest/bitstreams/1320080/retrieve.

16. WHO SAGE. (2020). Seasonal Influenza Vaccination Recommendations during the COVID-19 Pandemic Interim guidance.

17. WHO. (2021). The Oxford/AstraZeneca COVID-19 vaccine: what you need to know. Retrieved from: https://www.who.int/news-room/feature-stories/detail/the-oxford-astrazeneca-covid-19-vaccine-what-you-need-toknow. 
18. Who: Technical Advisory Group on Behavioural Insights and Sciences for Health. (2020). Behavioural Considerations for Acceptance and Uptake of Covid-19 Vaccines.

19. Wilson SL, Wiysonge C. Social media and vaccine hesitancy. BMJ Global Health. 2020;5(10):e004206.

20. World Health Organization. (2020). Survey Tool and Guidance: Rapid, Simple, Flexible Behavioural Insights on COVID19 https://www.euro.who.int.

21. Zimet GD, Silverman RD, Fortenberry JD. (2020). Coronavirus Disease 2019 and Vaccination of Children and Adolescents: Prospects and Challenges. The Journal of pediatrics.

\title{
Figures
}

\section{Vaccine Acceptance Rate}

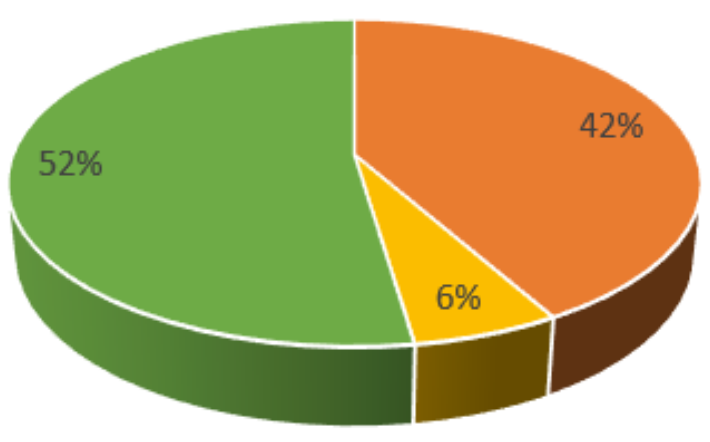

\author{
- I want to be among the \\ first to get it \\ - I will not get the vaccine \\ - I will wait to see how \\ other people react to it \\ before I can get it
}

\section{Figure 1}

Vaccine acceptance rate

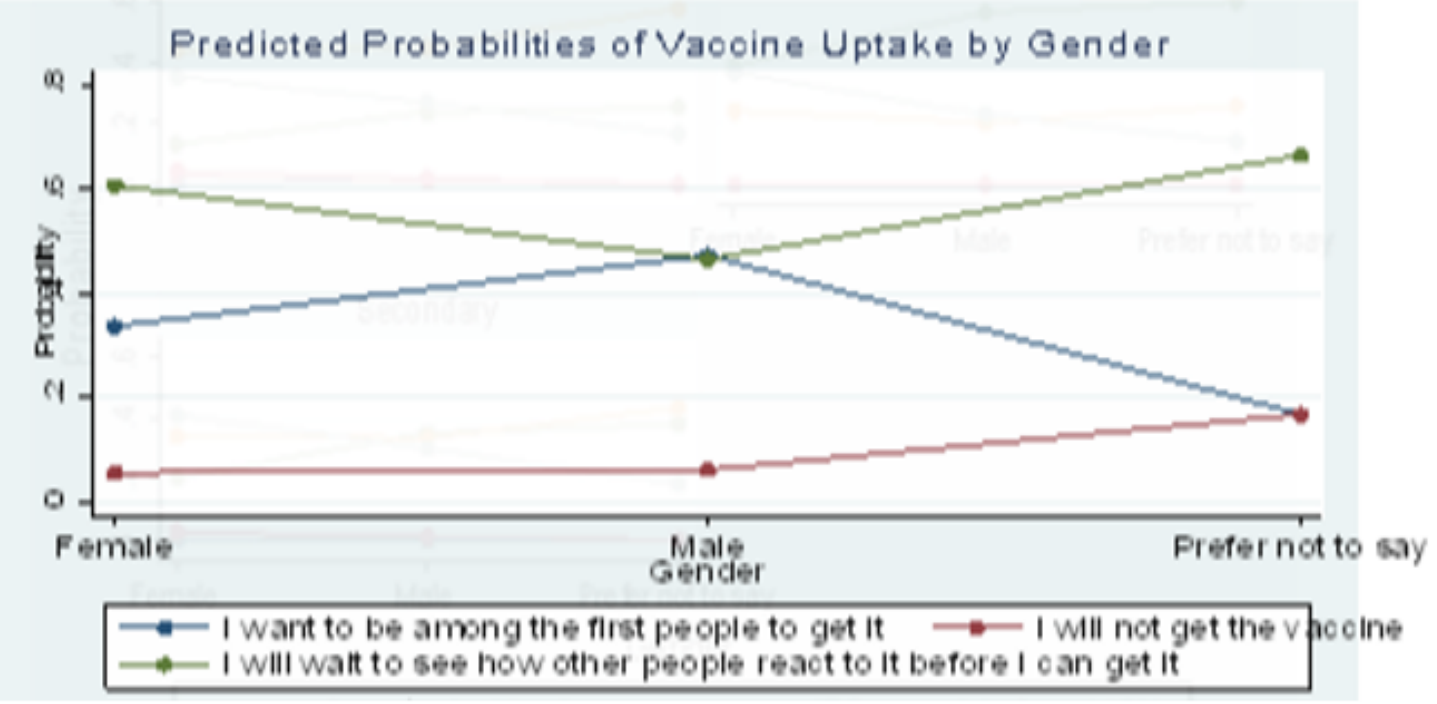

\section{Figure 2}

Vaccine uptake by gender 


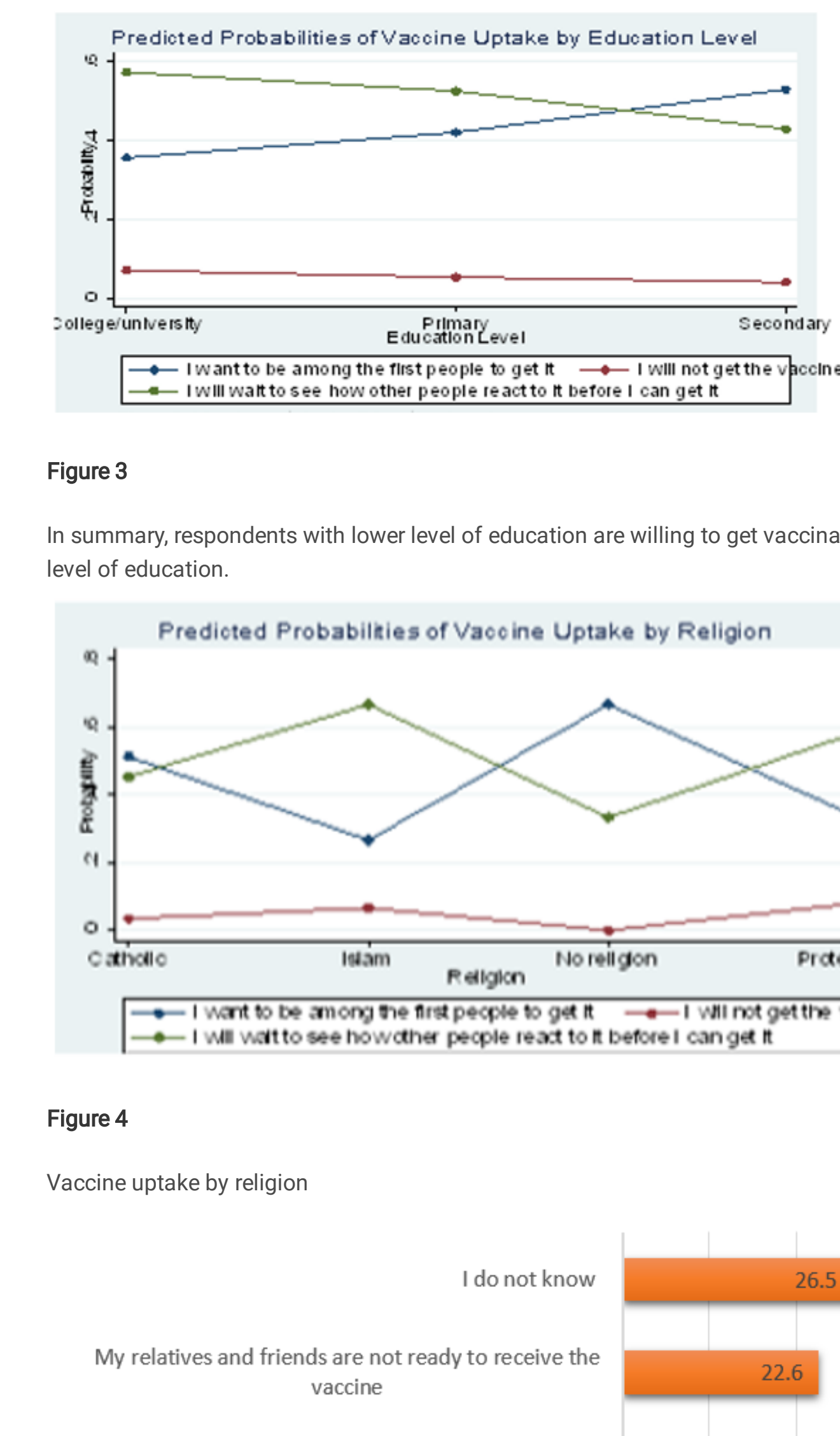

\section{Figure 3}

In summary, respondents with lower level of education are willing to get vaccinated compared to counterparts with higher level of education.

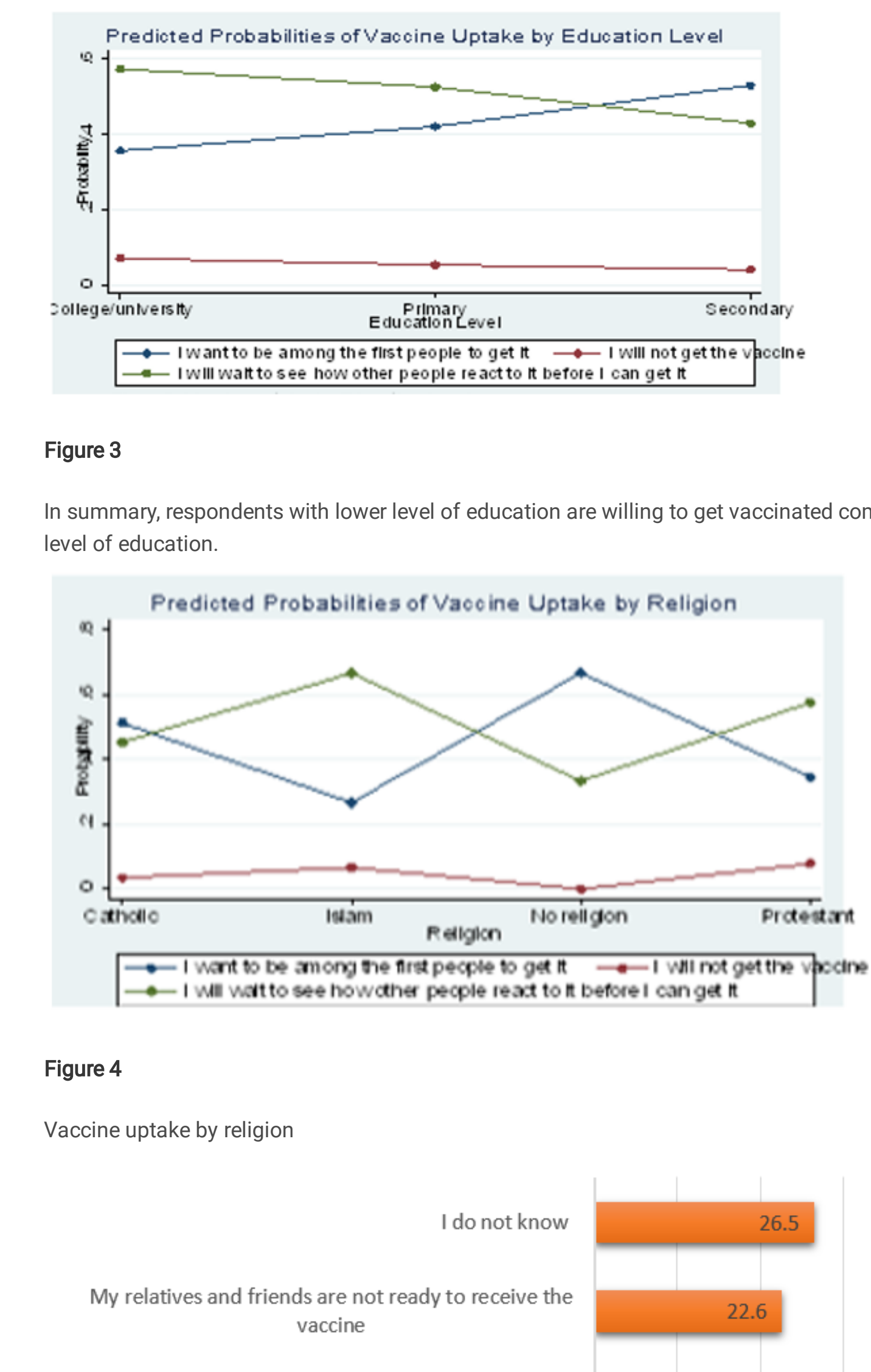

\section{Figure 4}

Vaccine uptake by religion

My relatives and friends are not ready to receive the vaccine

My relatives and friends are ready to receive the vaccine
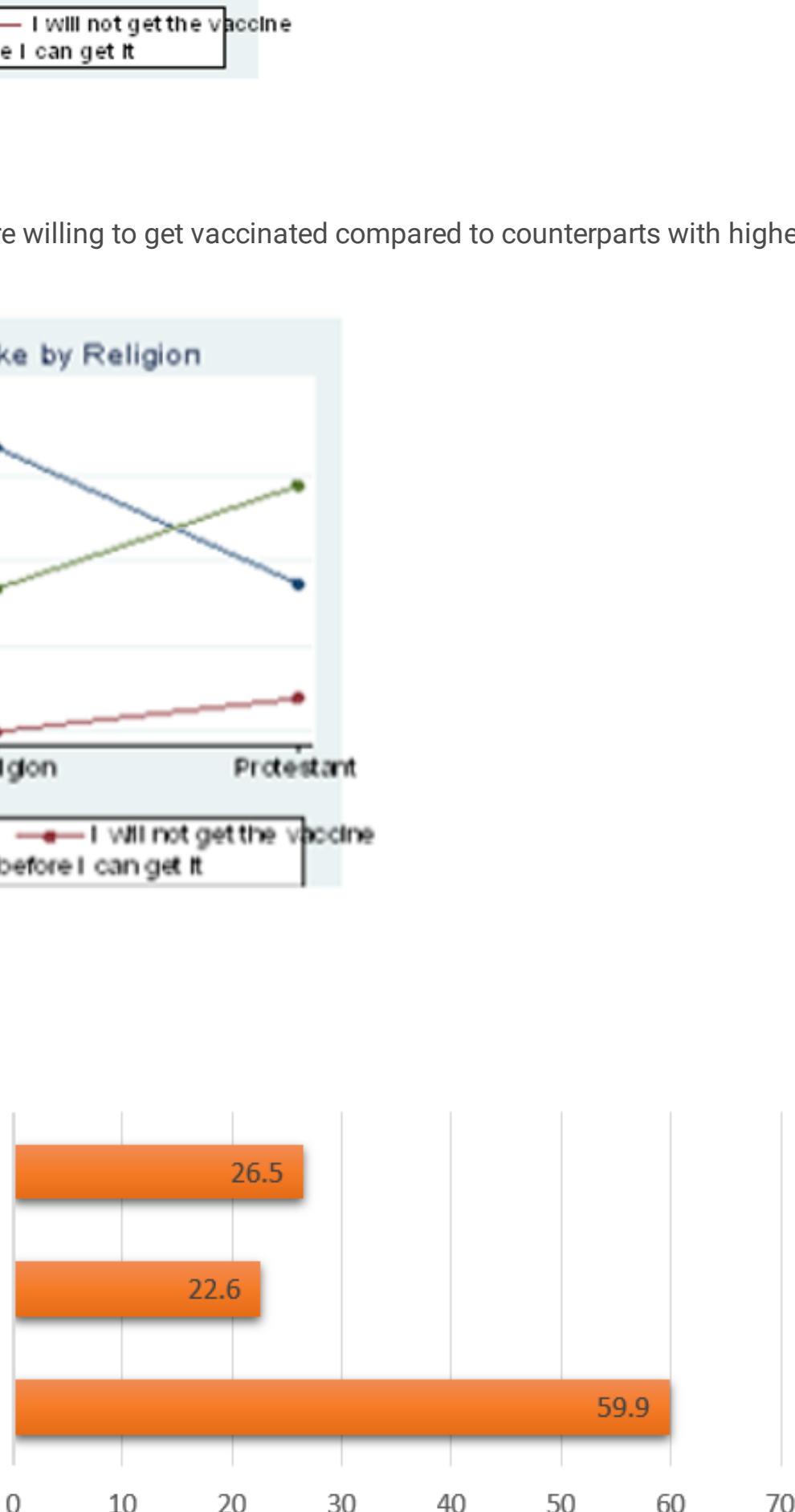
Figure 5

Youth's perception on what their friends and relatives want

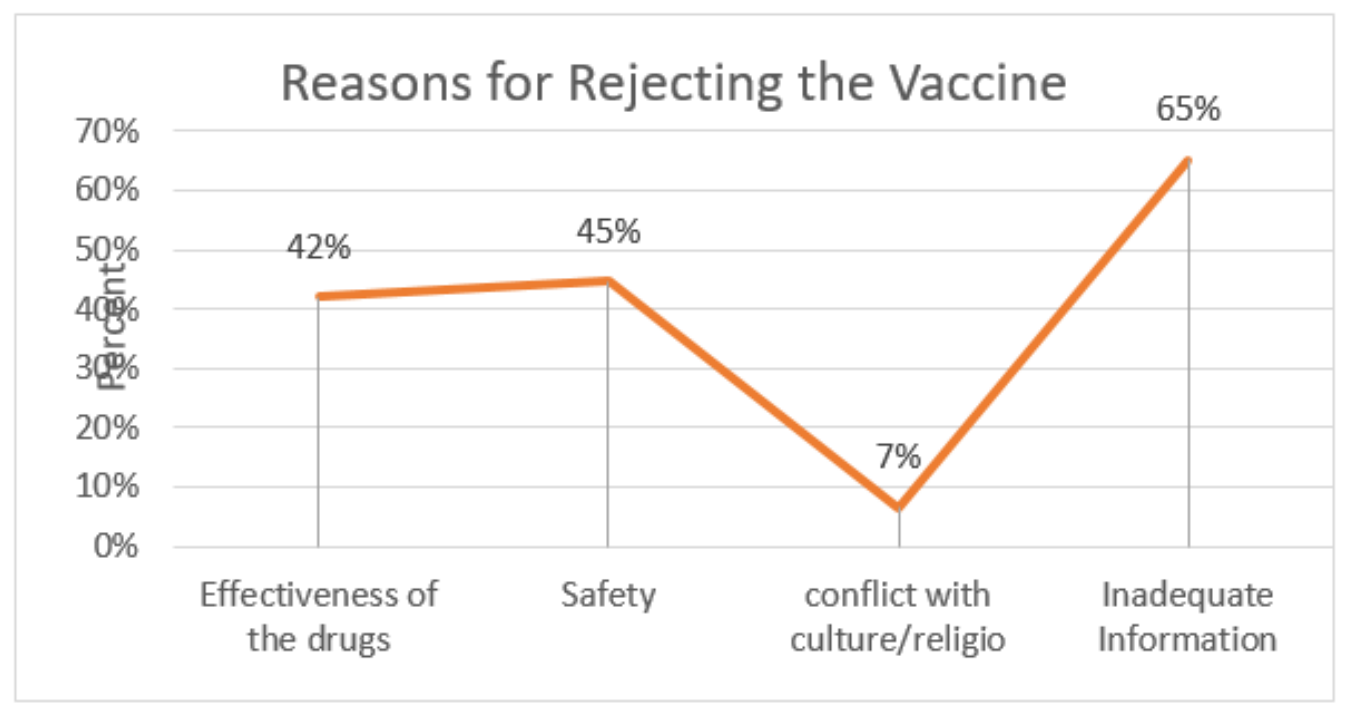

Figure 6

Reason for Rejecting COVID 19 Vaccine

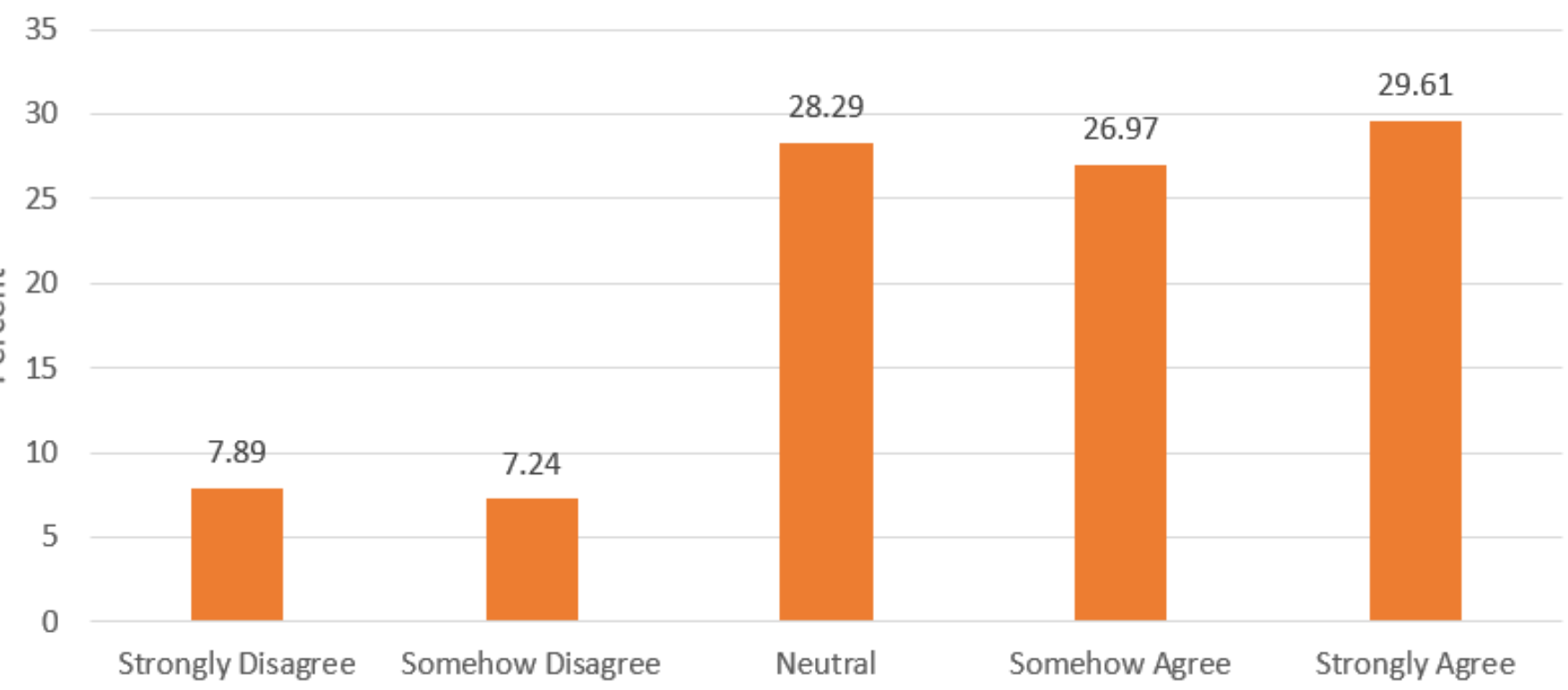

\section{Figure 7}

To what extend do you agree with their reason for rejecting COVID 19 vaccines Contextual Influences - communication and social media, gender and socio-cultural 


\section{Sources of Covid 19 Information}

\section{$50 \%$ \\ $45 \%$ \\ $40 \%$ \\ $35 \%$ \\ $30 \%$ \\ $25 \%$ \\ $20 \%$ \\ $15 \%$ \\ $10 \%$ \\ $5 \%$ \\ $0 \%$}

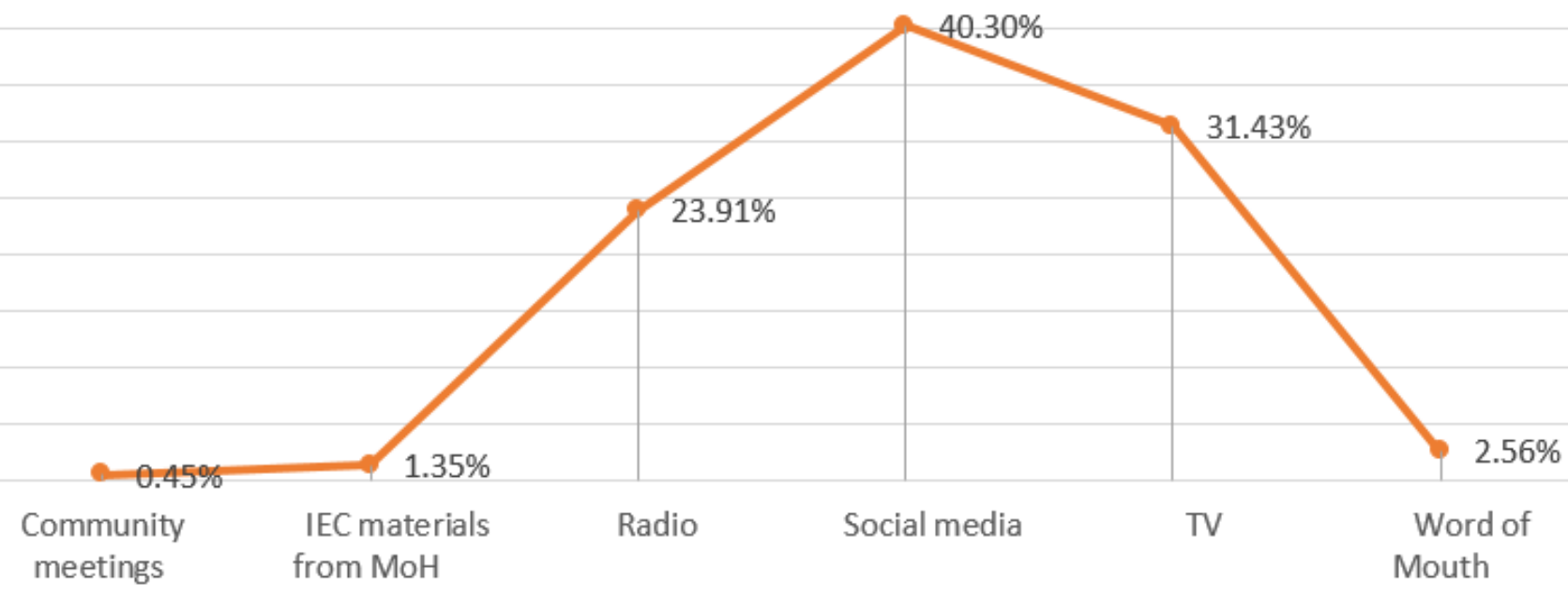

Figure 8

Sources of information on COVID-19 vaccination that you and your community come across

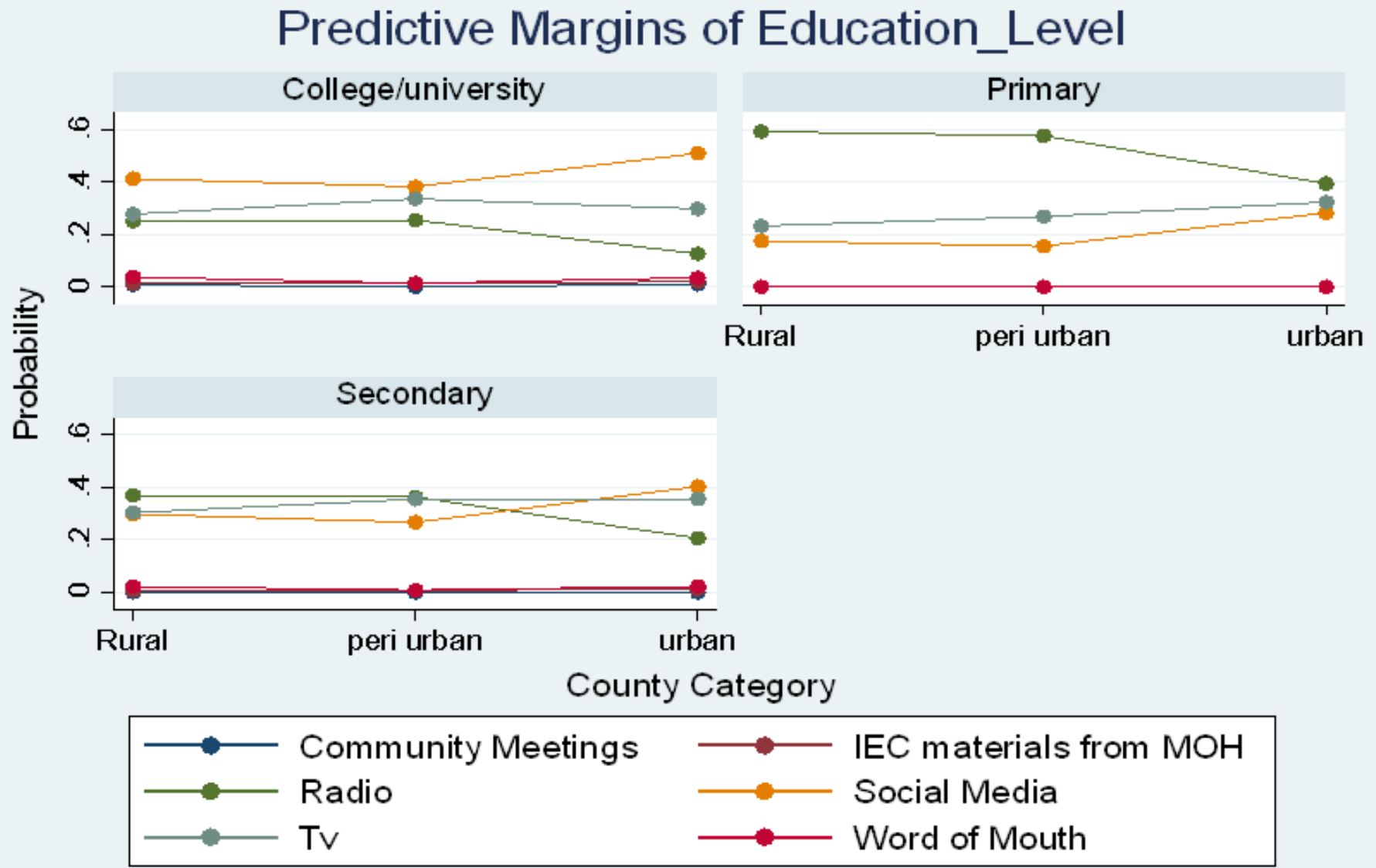

Figure 9 
Predicted Probabilities of each Source of information by Education level and county Category

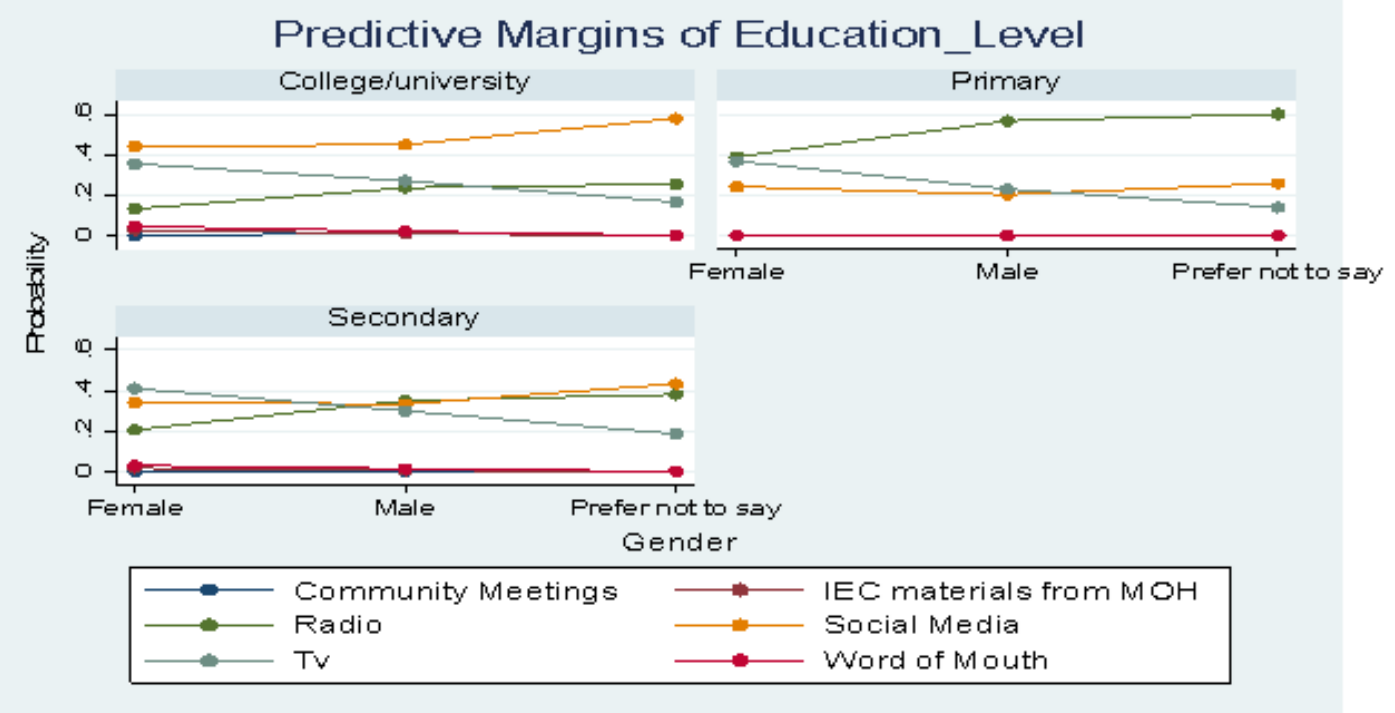

Figure 10

Predicted Probabilities of each Source of information by Education level and gender

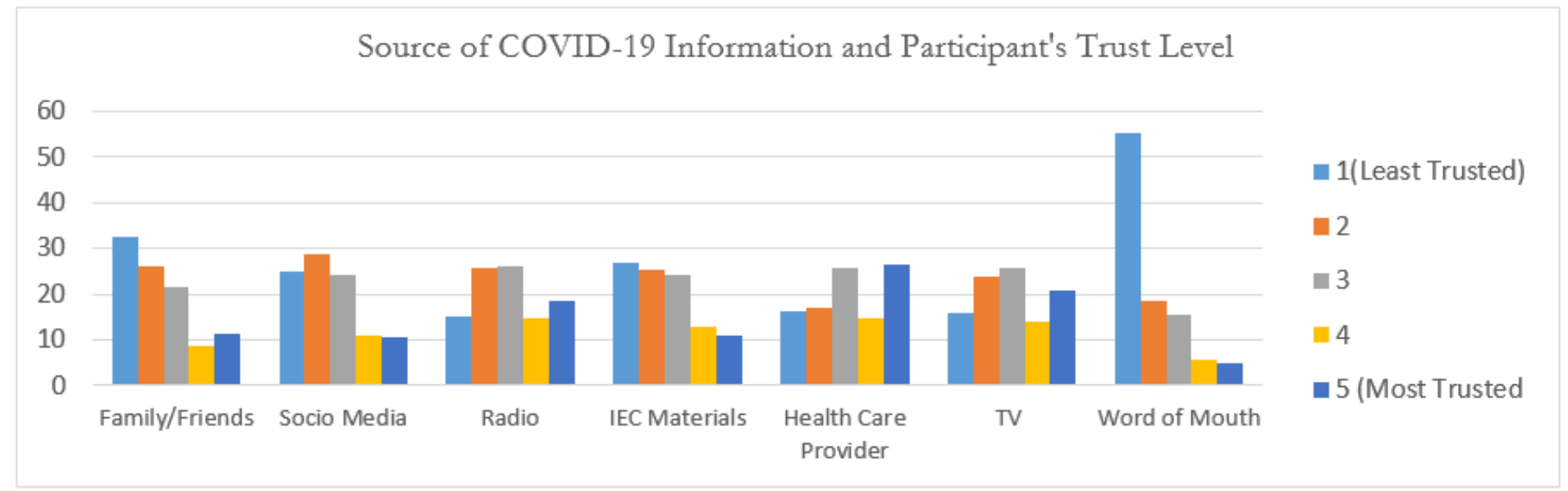

\section{Figure 11}

Degree of trust on Sources of information on COVID-19 vaccine

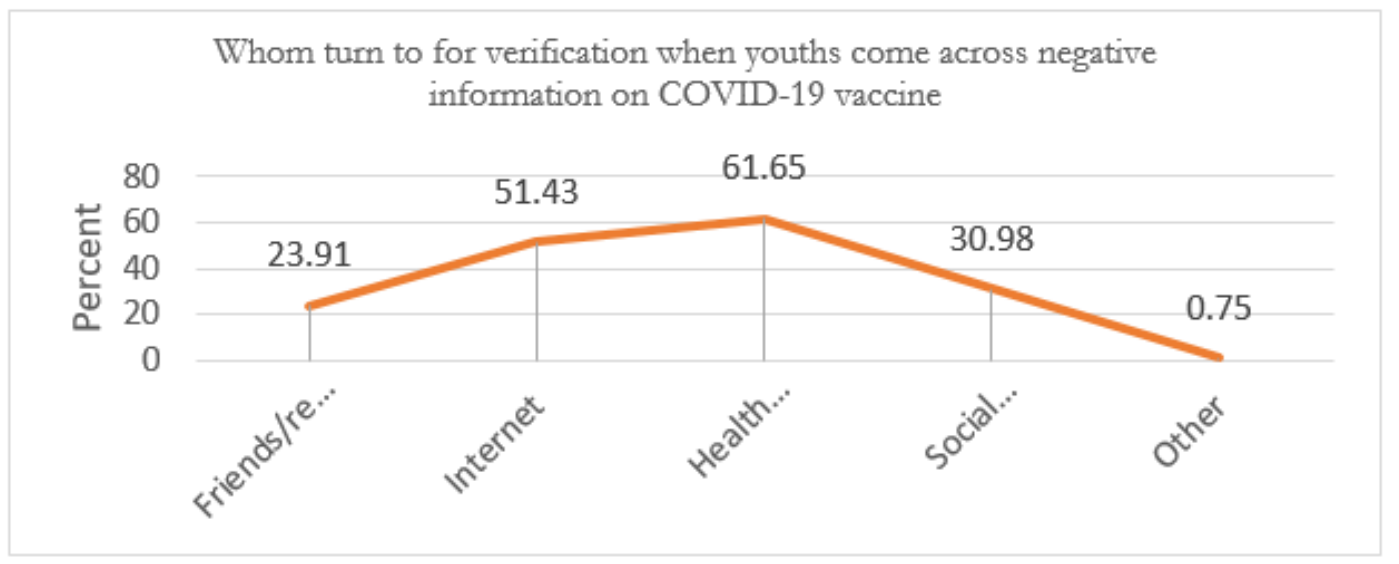




\section{Figure 12}

Whom turn to for verification when youths come across negative information on COVID-19 vaccine

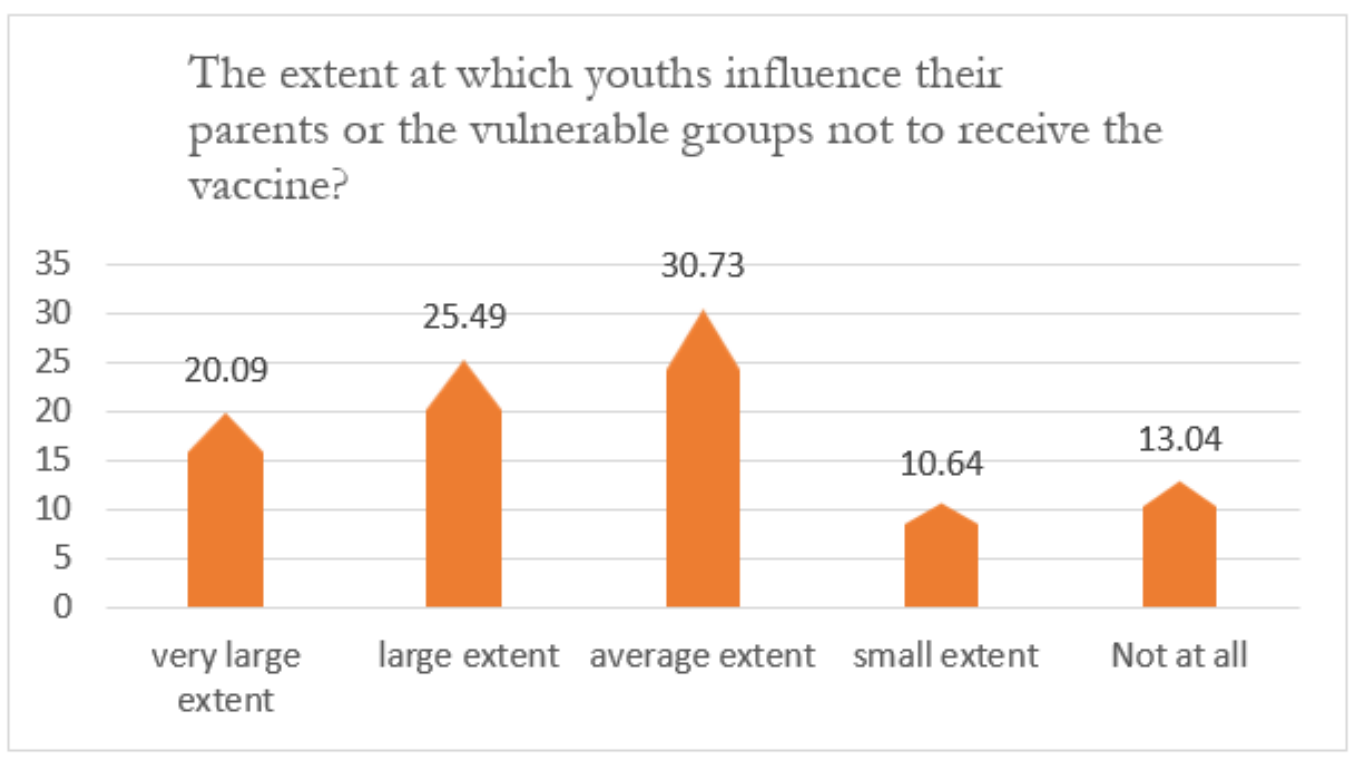

\section{Figure 13}

Youth Influence on the uptake of Vaccine 